\title{
Review
}

\section{The discovery of Hepatocyte Growth Factor (HGF) and its significance for cell biology, life sciences and clinical medicine}

\author{
By Toshikazu NAKamura ${ }^{* 1, * 2, \dagger}$ and Shinya MizUnO*2
}

(Communicated by Kunihiko SuZUKI, M.J.A.)

\begin{abstract}
It has been more than 25 years since HGF was discovered as a mitogen of hepatocytes. HGF is produced by stromal cells, and stimulates epithelial cell proliferation, motility, morphogenesis and angiogenesis in various organs via tyrosine phosphorylation of its receptor, c-Met. In fetal stages, HGF-neutralization, or $c$-Met gene destruction, leads to hypoplasia of many organs, indicating that HGF signals are essential for organ development. Endogenous HGF is required for self-repair of injured livers, kidneys, lungs and so on. In addition, HGF exerts protective effects on epithelial and non-epithelial organs (including the heart and brain) via anti-apoptotic and anti-inflammatory signals. During organ diseases, plasma HGF levels significantly increased, while anti-HGF antibody infusion accelerated tissue destruction in rodents. Thus, endogenous HGF is required for minimization of diseases, while insufficient production of HGF leads to organ failure. This is the reason why HGF supplementation produces therapeutic outcomes under pathological conditions. Moreover, emerging studies delineated key roles of HGF during tumor metastasis, while HGF-antagonism leads to anti-tumor outcomes. Taken together, HGF-based molecules, including HGF-variants, HGF-fragments and c-Met-binders are available as regenerative or anti-tumor drugs. Molecular analysis of the HGF-c-Met system could provide bridges between basic biology and clinical medicine.
\end{abstract}

Keywords: HGF, c-Met, regeneration, organ protection, embryogenesis, mesenchymalepithelial interaction

\section{Discovery of HGF as a hepatotrophic factor}

The liver plays diverse roles in the metabolism of the body and actively regenerates after partial hepatectomy or during hepatitis. Numerous biologists attempted to identify a phantom factor that acts as a trigger for liver regeneration after 70\%hepatectomy, since cross-circulation experiments in parabiotic rodents demonstrated that liver regeneration is initiated by a blood-born factor. Never-

*1 Kringle Pharma Joint Research Division for Regenerative Drug Discovery, Center for Advanced Science and Innovation, Osaka University, Osaka, Japan.

*2 Division of Molecular Regenerative Medicine, Department of Biochemistry and Molecular Biology, Graduate School of Medicine, Osaka University, Osaka, Japan.

$\dagger$ Correspondence should be addressed: T. Nakamura, Kringle Pharma Joint Research Division for Regenerative Drug Discovery, Center for Advanced Science and Innovation, Osaka University, 2-1 Yamadaoka, Suita 565-0871, Japan (e-mail: nakamura@casi.osaka-u.ac.jp). theless, such a humoral factor was not identified for the past more than 30 years, since a simple, sensitive and reliable in vitro assay system was not available until the early 1980's. Several studies, including our own, revealed that adult rat hepatocytes in primary culture retained numerous liver-specific functions and responded to various hormones. ${ }^{1)-4)}$ This fact encouraged us to identify as-yet-unknown hepatotrophic factor(s) via the establishment of an in vitro assay of DNA synthesis in adult rat hepatocytes. In this section, we describe the previous efforts leading to purification and cDNA cloning of HGF.

1-1. The challenge of establishing an in vitro assay for identifying hepatotrophic factors. In 1983, we demonstrated that adult rat hepatocytes in primary culture could proliferate at a low cell density in a medium containing insulin and epidermal growth factor (EGF) ${ }^{3)}$ providing an experimental tool for searching hepatotrophic factors. Using this assay system, we identified, in 1984, a putative hepato- 
trophic factor in the serum of 70\%-hepatectomized rats. This factor stimulated DNA synthesis and proliferation of adult rat hepatocytes in primary culture and we named it as "Hepatocyte growth factor" or "Hepatotropin". 5) Our in vitro assay system also contributed to "complete purification" of rat HGF from the platelets of 3,000 rats and revealed that it was a new growth factor. $\left.{ }^{6)}, 7\right)$ This successful purification of native $\mathrm{HGF}$ led to the successful cloning of HGF cDNA as well as to the determination of the complete amino acid sequences of rat and human HGF, as described later.

1-2. Chemical properties of HGF. HGF was purified to homogeneity from rat platelets using a four-step procedure including heparin-affinity chromatography. ${ }^{6), 7)}$ We noticed in 1984 that HGF had an affinity for heparin-sepharose CL-6B during a survey of ligands for affinity chromatography of HGF. ${ }^{5)}$ Consequently, HGF was purified from rat platelets to homogeneity in only four steps, resulting in a high yield. ${ }^{7}$ ) Other investigators also used heparin-affinity chromatography for purification of HGF either from the plasma of patients with hepatitis $^{8)}$ or from healthy volunteers. ${ }^{9 \text { ) }}$

HGF has a molecular weight of $84 \mathrm{kDa}$ on SDSPAGE. ${ }^{7)}$ Under reducing conditions, it gives two bands with molecular weights of $69 \mathrm{kDa}$ and $34 \mathrm{kDa}$, respectively. Thus, HGF is a dimeric molecule composed of an $\alpha$-subunit $(69 \mathrm{kDa})$ and a $\beta$-subunit $(34 \mathrm{kDa})$, respectively, linked by a disulfide bond. $\mathrm{HGF}$ is a heat-labile protein; it loses activity appreciably when heated to $56^{\circ} \mathrm{C}$ for $30 \mathrm{~min}$ or completely when boiled for $1.5 \mathrm{~min}$. Activity is also partially lost after treatment with acetic acid and completely lost by trypsin treatment.

1-3. Molecular cloning and primary structure of HGF. We first succeeded in 1988 for partial cloning of rat HGF cDNA from a liver cDNA library using the N-terminal sequence of rat HGF $\beta$-chain. Northern blot hybridization using rat HGF cDNA revealed that the size of HGF mRNA was about $6 \mathrm{~kb}$. Thus, both rat and human HGF cDNA were screened from the human and rat liver cDNA library using the rat $\mathrm{HGF}$ cDNA as a probe. Finally, full-sized cDNA of both rat and human HGF were cloned in 1989. ${ }^{10), 11)}$ The nucleotide sequence comprises a single open reading frame of 2,184 nucleotides and 3,580 nucleotides of 3 '-non-coding regions. In the open reading frame, we also confirmed the 19 amino acid residues of the $\mathrm{N}$-terminus of the $\alpha$-subunit for rat HGF. The C-terminus of the $\alpha$-subunit is followed directly by the N-terminus of the $\beta$-subunit. The sequence at the cleavage site between the $\alpha$ - and $\beta$ subunit is Arg 494-Val 495, and this site is cleaved by serine proteases. Overall, HGF is synthesized as a pro-HGF of 728 amino acids and then mature HGF is formed by proteolytic cleavage (Fig. 1A). In mature HGF, Cys 487 in the $\alpha$-chain and Cys 604 in the $\beta$ chain form an interchain bridge. Human HGF cDNA was also cloned by Miyazawa et al. ${ }^{12)}$

1-4. Both scatter factor and tumor cytotoxic factor are identical to HGF. Scatter factor (SF) was first identified as a human embryonic fibroblast (MRC5)-derived protein that enhances motility of renal tubular cells (MDCK). ${ }^{13)}$ We found that the motogenic activity of SF was abolished by adding anti-HGF antibody, while HGF also mimicked the scatter activity in a culture of MDCK. ${ }^{14)}$ Moreover, MRC5 cells expressed $6 \mathrm{~kb}$ mRNA, which was hybridized with a HGF cDNA probe, and SF cDNA cloned from the MRC5 cDNA library had the same sequence as that of cDNA from human leukocytes, thus eventually indicating that $\mathrm{SF}$ is identical to HGF. ${ }^{14), 15)}$

HGF was originally discovered as a mitogen of adult rat hepatocytes ${ }^{5)-7)}$ whereas HGF has a cytotoxic effect on certain tumor cells, such as hematoma, HepG2. ${ }^{16)}$ With regard to this, Higashio et al. found that human lung fibroblasts (IMR-90) secrete a soluble factor capable of killing Sarcoma180 and named it tumor cytotoxic factor (TCF). The chemical properties of TCF were almost similar to those of HGF. This group isolated TCF cDNA from the cDNA library of IMR-90 cells. As a consequence, TCF was found to be molecularly identical to HGF. ${ }^{17)}$

1-5. c-Met, an oncogenic gene product, is an HGF-receptor. While HGF was discovered in the sera of $70 \%$-hepatectomized rats, ${ }^{5)}$ the $c$-Met protooncogene product (c-Met) had been identified as a new member of the tyrosine kinase family, possibly as a new receptor of unknown growth factor(s): Bottaro et al. found in 1992 that c-Met is a receptor for HGF: ${ }^{18)}$ A 145-kDa tyrosyl phosphoprotein observed in rapid response to $\mathrm{HGF}$-addition of target cells was identified by immunoblots as the $\beta$-subunit of the $c$-Met proto-oncogene product. Furthermore, we obtained direct evidence that c-Met is bound to HGF with a high affinity $(\mathrm{Kd}=30 \mathrm{pM})$ after a transfection of the human c-Met cDNA-carrying plasmid into COS-7 cells, ${ }^{19)}$ thus identifying the $c$-met product as the high-affinity receptor for $\mathrm{HGF}$.

c-Met is composed of a $50 \mathrm{kD} \alpha$-chain and a $145 \mathrm{kD} \beta$-chain. ${ }^{18)}$ The $\alpha$-chain is exposed extracell- 

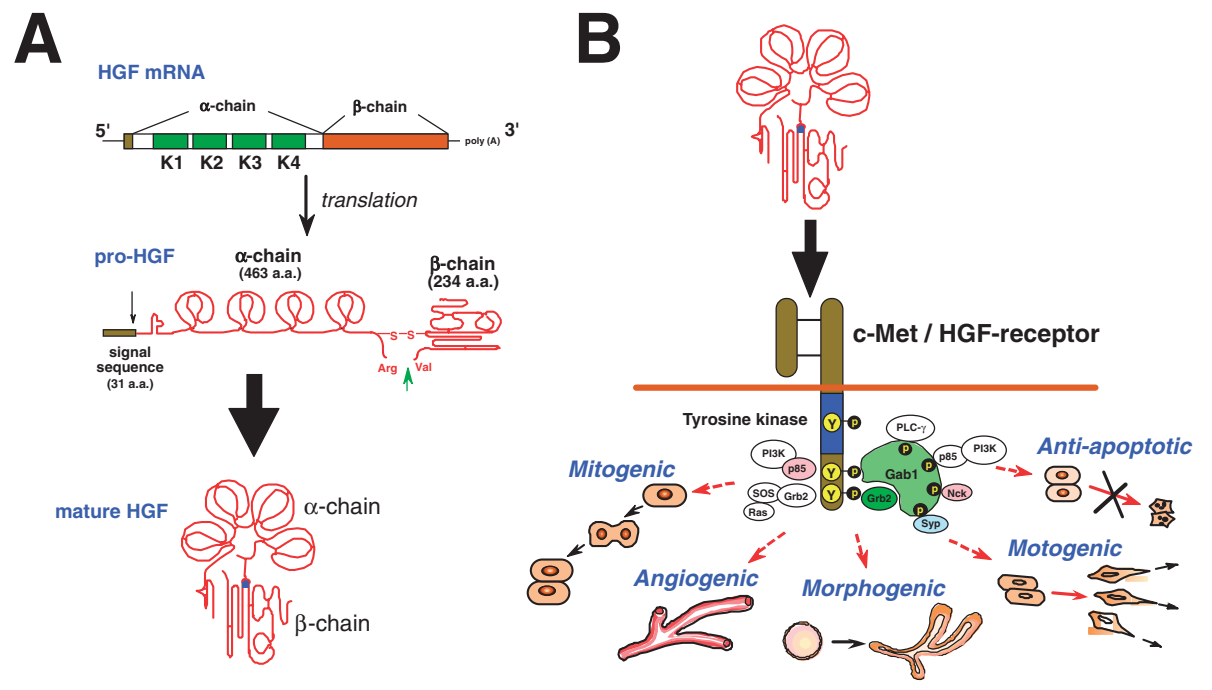

Fig. 1. Structure and biological function of HGF. (A) Production and activation of HGF. HGF is produced and secreted as a pro-HGF by stroma cells such as fibroblasts, macrophages, renal mesangium and so on. Secreted pro-HGF is cleaved at $\mathrm{Arg}^{494}$ and $\mathrm{Val}^{495}$ by HGF-activators, such as urokinase-type plasminogen activator (uPA). (B) Multi-faceted biological actions of HGF mediated via the c-Met/HGF-receptor. Binding of HGF to c-Met leads to tyrosine phosphorylation, and each biological activity is elicited via the recruitment of down-stream adaptor molecules (see, section 4 ).

ularly, while the $\beta$-chain is a transmembrane subunit containing an intracellular tyrosine kinase domain. Binding of HGF to c-Met induces phosphorylation of C-terminally clustered tyrosine residues of tyrosine kinase, which results in biological activities in a wide variety of cells, including mitogenic, motogenic and morphogenic activities ${ }^{20)-22)}$ (Fig. 1B). The biological activities of HGF, required for restoring organ diseases, are discussed later (see, section 5).

\section{Hepatotrophic roles of HGF during liver regeneration}

Liver regeneration is recognized as an example of controlled tissue growth. ${ }^{23)}$ Originally, HGF was identified in the sera of $70 \%$-hepatectomized rats, as a mitogen of adult rat hepatocytes. ${ }^{5), 20)}$ Indeed, during hepatic injuries, blood and liver HGF levels markedly increased, via both extra-hepatic and intra-hepatic pathways. ${ }^{21), 24)}$ Animal studies using either anti-HGF antibody or $c$-Met gene destruction techniques revealed that both the endocrine and paracrine effects of $\mathrm{HGF}$ are involved in liver growth after 70\%-hepatectomy, and for recovery from hepatitis, respectively. ${ }^{21), 25)}$ This concept is conserved in numerous organs. Herein, we describe the mechanisms whereby liver regeneration is regulated, through sequential molecular events, focusing on the function of the HGF-c-Met system.
2-1. Essential roles of HGF for liver growth after $\mathbf{7 0 \%}$-hepatectomy. There were two-waved increases of plasma HGF levels in the 70\%-hepatectomized rats, which had preceded the initiation of hepatocyte duplication. ${ }^{24)}$ Northern blot analysis revealed that HGF mRNA levels had markedly increased in intact distant organs, such as lungs, kidneys and spleens, rather than in the remnant livers, post-70\%-hepatectomy. ${ }^{24), 26)}$ These studies were the first to imply the importance of the "endocrine" system for delivering HGF into the remnant lobes via the portal vein (Fig. 2).

The fact that blood-born HGF triggers liver regeneration was demonstrated in 1992: when recombinant human HGF (rh-HGF) was intravenously administrated into hepatectomized mice, hepatocyte duplication was enhanced. ${ }^{27)}$ Inversely, anti-HGF $\mathrm{IgG}$ diminished the regenerative responses (i.e., $\mathrm{G}_{1} / \mathrm{S}$ progression) of hepatocytes after liver injuries. ${ }^{28), 29)}$ Such a regenerative role of endogenous HGF-c-Met was also observed in liver-specific c-Metdeficient mice. ${ }^{30)}$ These findings indicate that the production of HGF by distant organs (such as lung and spleen) acts in an endocrine manner to drive liver regeneration post-70\%-hepatectomy.

2-2. HGF-c-Met axis for in situ repair during acute hepatitis. During hepatitis, destructed areas of hepatocytes are replaced with neo-generated hepatocytes, and this regenerative fashion is defined 


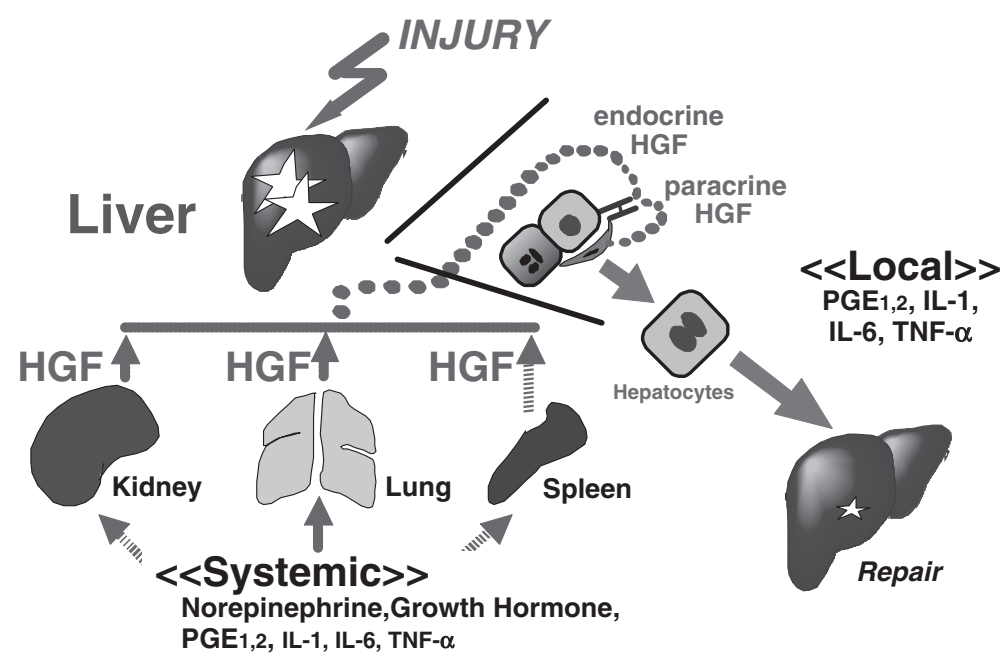

Fig. 2. Critical roles of the HGF-c-Met system during liver regeneration. During liver injury, HGF is produced by distant organs (i.e., kidney, lung and spleen) in response to HGF-inducers, such as norepinephrine, growth hormone, prostaglandins and cytokines (i.e., endocrine system). Furthermore, HGF is produced in sinusoidal cells, such as Kuppfer cells (i.e., paracrine system). Both systems are required for compensatory liver growth and in situ repair.

as an in situ repair. Experimentally, chemical toxins, such as carbon tetrachloride $\left(\mathrm{CCl}_{4}\right)$, induce acute hepatitis in laboratory animals, which mimics a pathological status in humans. Using $\mathrm{CCl}_{4}$-treated rodents as a model for hepatitis, we have accumulated evidence showing that the paracrine system for the production and delivery of HGF is also required for recovery from hepatitis (Fig. 2).

In contrast to $70 \%$-hepatectomy, an increase in HGF mRNA levels is more evident and occurs earlier in the liver than in distant organs in rats during acute hepatitis. ${ }^{31)}$ In situ hybridization identified sinusoidal cells (including Kupffer cells) as the source of HGF during hepatitis. ${ }^{32)}$ Notably, anti-HGF IgG reduced the number of proliferating hepatocytes after $\mathrm{CCl}_{4}$ injection. ${ }^{28)}$ Such a role of the HGF-c-Met axis for reversing hepatitis is reproducible in liver-specific $c$-Met-knockout mice, ${ }^{30)}$ indicating that the paracrine signal elaborated from neighboring cells (such as Kupffer cells) is critical for morphological and functional recovery from hepatitis.

2-3. Sensing systems for HGF production during liver regeneration. HGF is now recognized as a hepato-regenerative factor during liver injuries. Thus, it is important to elucidate the mechanism whereby the host cells produce and deliver HGF to injured sites in a response that is commensurate with the type and degree of liver insult. Although the identification of HGF-inducers in the plasma or injured livers remains to be addressed, several known molecules are involved in the up-regulation of HGF gene expression.

For example, pro-inflammatory cytokines are produced by resident or infiltrated macrophages in the injured livers. Among these mediators, interleukin (IL)-1, IL-6, interferon- $\gamma$ and tumor necrosis factor- $\alpha$ (TNF- $\alpha)$ are involved not only in the priming of hepatocytes for $\mathrm{G}_{0}$-to- $\mathrm{G}_{1}$ conversion ${ }^{23)}$ but also in the up-regulation of HGF expression. ${ }^{33)}$ In other words, inflammatory mediators (such as IL-6/TNF- $\alpha$ ) may participate in liver regeneration, as a co-mitogen for $\mathrm{G}_{0} / \mathrm{G}_{1}$ priming (i.e., direct effect), ${ }^{23)}$ and later, as an inducer of HGF for the inevitable $\mathrm{G}_{1} / \mathrm{S}$ progression (i.e., indirect effect) post-hepatectomy.

Blood hormones and neuro-transmitters may be involved in the endocrine system of HGF. For example, growth hormone accelerated liver growth post-hepatectomy in hypophysectomized rats, and this was linked with the up-regulation of HGF production. ${ }^{34)}$ Blood norepinephrine (NE) levels are increased after 70\%-hepatectomy, while $\alpha 1$ adrenoreceptor blockers inhibits liver growth. NE can enhance HGF production in cultured fibroblasts, ${ }^{35)}$ thus suggesting an involvement of $\mathrm{NE}$ in liver regeneration. Systemic prostaglandin-E is involved in liver growth post-hepatectomy, while prostaglandin-E stimulates HGF production, ${ }^{36)}$ suggesting roles of prostaglandins-HGF pathways in liver regeneration. 

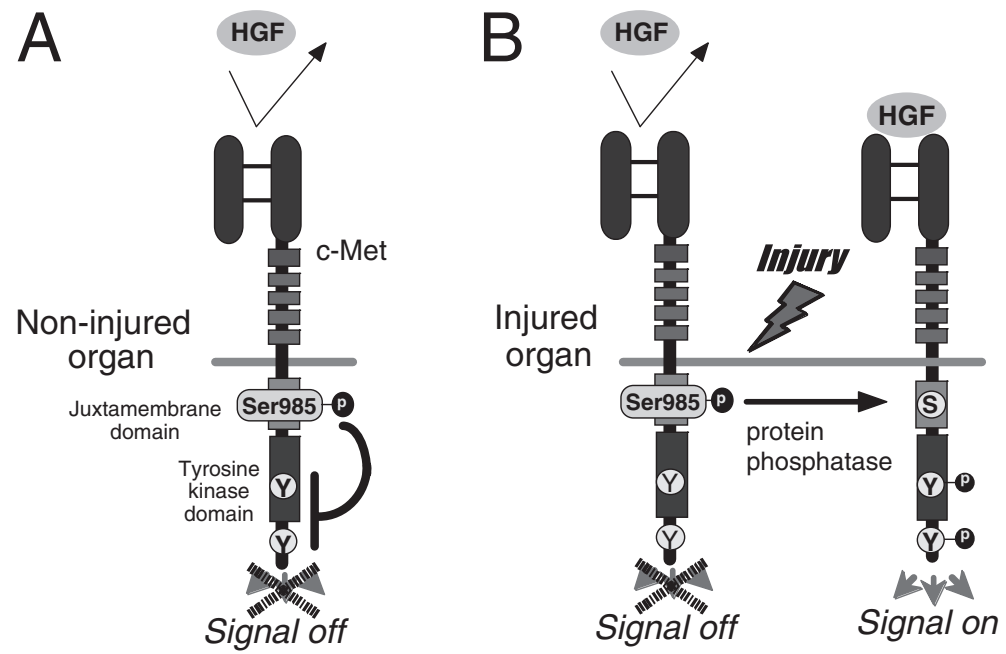

Fig. 3. A hypothetical model for injury-specific HGF/c-Met intracellular signaling. (A) In non-injurious (i.e., normal) organ tissues, a serine residue site at position 985 (Ser-985) in the juxtamembrane of c-Met is constitutively phosphorylated and functions as a negative regulator to inhibit HGF-Met signaling (i.e., switch OFF). (B) Once organ tissues undergo injuries, Ser-985 site is "de-"phosphorylated, probably via recruitment of intracellular PP2A. As a result, c-Met tyrosine sites are phospholylated, and then pleiotropic activities are delivered (i.e., switch $\mathrm{ON}$ ).

In summary, pro-inflammatory cytokines may trigger HGF production in intra-hepatic tissues (i.e., as a paracrine loop) and in extra-hepatic organs (i.e., as an endocrine system). In addition, humoral mediators, such as neuro-transmitters, hormones and autacoids may be involved in the endocrine mechanism of HGF production (Fig. 2). ${ }^{34-37)}$

2-4. Injury organ-specific signal transduction of HGF. An increase in plasma HGF levels means a systemic exposure of numerous organs to circulating $\mathrm{HGF}$, but $\mathrm{HGF}$ is accumulated predominantly in injured organs. ${ }^{38)}$ In other words, intact organs can escape c-Met activation by blood HGF, probably due to no need for tissue repair, although the molecular basis of this phenomenon remains unclear. Using an in vitro assay, we found that a serine residue at position 985 (Ser-985) in the juxtamembrane of c-Met acts as a negative regulator to limit HGF-c-Met signaling. ${ }^{39)}$ Under Ser-985-phosphorylated conditions, HGF fails to induce a scattering of epithelium, while the release of Ser-985 phosphorylation by protein phosphatase2A (PP2A) allowed for c-Met tyrosine phosphorylation and migration of epithelium. ${ }^{39)}$ Thus, the reciprocal balance between phosphorylation of Ser985 and tyrosine may be a key determinant of HGF-cMet signaling - in non-injurious tissues, Ser-985 is always phosphorylated, which leads to the inhibition of c-Met tyrosine phosphorylation, even in the presence of HGF. However, once the tissues undergo parenchymal injuries, the Ser-985 site is de-phos- phorylated via recruitment of PP2A. Overall, c-Met tyrosine is phosphorylated in response to HGF, leading to the regenerative outcomes (Fig. 3).

\section{Regenerative roles of HGF in other organs}

Several lines of in vitro studies have revealed that HGF has regenerative effects on epithelium in the kidney, lung and other tissues. ${ }^{20), 21), 25), 40)}$ Indeed, plasma HGF levels are elevated in patients during organ injuries. ${ }^{41)}$ The administration of anti-HGF IgG is known to result in the inhibition of epithelial repair in numerous organs of rodents. Based on these data, we emphasize the common mechanism of HGF for tissue repair in many organs, such as the kidney, as follows.

3-1. Renal regeneration. As with the liver, compensatory growth occurs in remnant kidneys after partial nephrectomy in adaptation to a loss in the number of nephrons. Although the existence of blood-born renotrophic factors has been implicated, these factors remain to be identified. Prior to the initiation of renal regeneration, HGF mRNA and protein levels increase in remnant kidneys and intact organs (such as lungs), ${ }^{42), 43)}$ thus suggesting that paracrine and endocrine mechanisms of HGF are involved in renal regeneration. We found in 1994 that exogenous HGF increased the number of regenerating tubular cells in the right kidney after a left nephrectomy. ${ }^{44)}$ Renal growth is also observed after unilateral ureter-ligation (UUO), along with the 
increase in $\mathrm{HGF}$ production. ${ }^{45)}$ Of note, anti-HGF IgG decreased the proliferating tubular cells, ${ }^{45)}$ thus indicating that UUO-induced renal growth is mediated, in part, via the HGF-c-Met system.

In addition to compensatory growth, HGF is required for in situ repair during acute renal failure (ARF). In the mid-1990s, we found that administration of rh-HGF enhanced tubular regeneration in mice treated with renal toxins. ${ }^{43), 44)}$ In the mid2000's, we demonstrated, using a model of ischemic $\mathrm{ARF}$, that endogenous HGF is important for maintaining renal homeostasis ${ }^{46), 47)}$ : there was a twowaved increase (i.e., 1 and 24 hours) in plasma HGF levels after renal ischemia. Notably, anti-HGF IgG antibody enhanced tubular apoptosis in the early stage of $\mathrm{ARF}^{46)}$ and inhibited the proliferation of tubular cells in the later stage, ${ }^{47)}$ thus indicating that endogenous HGF is anti-apoptotic and mitogenic for protection and recovery from ARF, respectively.

3-2. Lung regeneration. Following acute lung injury in rodents, HGF mRNA and protein levels apparently increased within 24 hours after the challenge, and then lung alveolar and bronchial epithelium entered into a $\mathrm{G}_{1} / \mathrm{S}$-stage. ${ }^{48)}$ Furthermore, exogenous HGF administration enhanced mitogenesis in the lung airways and alveoli of mice after lung injury. ${ }^{49)}$ Direct evidence showing a contribution of endogenous HGF was demonstrated in two studies using rodent models. ${ }^{50), 51)}$ Transient lung ischemia led to alveolar destruction in rats, while alveolar repair became evident 4 days post-ischemia, and was associated with an increase in HGF production. ${ }^{50)}$ Notably, anti-HGF IgG treatment diminished alveolar cell proliferation in a rat model of ischemia. ${ }^{50)}$ The same results were obtained in a mouse model of lobectomy, where compensatory growth of lungs was impaired by anti-HGF IgG. ${ }^{51)}$ These studies clearly demonstrated a major role for endogenous HGF during lung repair and growth - even in adulthood.

3-3. Mucosal repair in gastro-intestines. In gastro-intestinal organs, mucosal membrane is always exposed to chemical and mechanical stress during the digestion and absorption of foods. Thus, the affected mucosa must be quickly repaired via movement of daughter epithelial cells. Exogenous HGF accelerates the healing of gastric injuries. ${ }^{52), 53)}$ By contrast, the inhibition of c-Met activation by anti-HGF IgG in the gastric mucosa suppressed the proliferation and movement along of the folds of the mucosal epithelial cells. ${ }^{53)}$ As a result, gastric mucosal integrity continued to be impaired under HGF-neutralized conditions. Similar results were seen in a mouse model of colitis, where the mucosal injuries were aggravated and accompanied by a decrease in c-Met tyrosine phosphorylation. ${ }^{54}$ In the gastro-intestinal tissues, $\mathrm{HGF}$ is constitutively produced by stromal cells in the sub-mucosa, while c-Met is over-expressed on the mucosal epithelium. Such a paracrine loop serves as a molecular surveillance system to avoid ulcer formation.

3-4. Physiological roles of HGF in other organs. The local HGF-c-Met systems are involved in not only tissue repair but also in metabolic homeostasis. HGF stimulates mitogenesis and insulin production in pancreatic $\beta$-cells. ${ }^{55)} \mathrm{HGF}$ is produced by $\alpha$-cells and regulates insulin production in $\beta$-cells to prevent hyperglycemia. ${ }^{55)}$ Importantly, $\beta$-cellspecific ablation of c-Met resulted in a reduction of islet size, a decrease in blood insulin levels, and eventually onset of mild hyperglycemia in mice. ${ }^{56)}$ These findings indicate that local HGF-c-Met system is required for control of blood glucose levels.

$\mathrm{HGF}$ is required for self-repair after the injuries of skin, muscle and cartilage; anti-HGF IgG diminished the proliferation and migration of keratinocytes during wound healing in mice. ${ }^{57}$ In addition, HGF-c-Met signaling is responsible for hair follicle morphogenesis and cycling in skin. ${ }^{58)}$ During muscular damage, $\mathrm{HGF}$ is produced by myogenic cells (i.e., autocrine pathway). When anti-HGF IgG was injected into mice during a muscular damage, myoblast duplication and muscular fiber formation were suppressed. ${ }^{59)}$ HGF is a mitogen of chondrocytes in vitro and attenuates the cartilage damage in rabbit knees. ${ }^{60)}$

$\mathrm{HGF}$ is also required for hematopoiesis. We found that $\mathrm{HGF}$ promotes the proliferation and colony formation of hematopoietic progenitors in vitro. ${ }^{61), 62)}$ In a line of HGF-transgenic mice, platelet counts were increased, ${ }^{63)}$ probably via enhancement of thrombopoietin production in hepatocytes. Of note, hepatic hematopoiesis is impaired in c-Metdeficient fetal mice. ${ }^{64)}$

In summary, endogenous HGF is important for inducing self-repair responses in numerous organs (Table 1). The paracrine or endocrine pathway that is predominantly involved in tissue repair depends on the degree, or kind, of injury. ${ }^{20), 25)}$ Regardless of the pathway, HGF is secreted as a pro-HGF and then converted to the active form only at the injury sites by HGF-activators. ${ }^{21), 41)}$ This local activation system may explain the injury-specific c-Met activation that elicits a regenerative response only in an injured organ. 
Table 1. Importance of endogenous HGF-c-Met system during organ regeneration or homeostasis

\begin{tabular}{|c|c|c|c|}
\hline Organ and injury & Treatment (Animals) & Outcomes & Ref. no \\
\hline \multicolumn{4}{|l|}{ Liver: } \\
\hline$\overline{\text { Compensatory growth }}$ & 70\%-hepatectomy (c-Met-KO mice) & $\begin{array}{l}\text { Suppression of hepatocyte proliferation, } \\
\text { Lipidosis }\end{array}$ & Huh-CG et al. [30] \\
\hline Acute hepatitis & $\mathrm{CCl}_{4}+$ Anti-HGF IgG (Mice) & $\begin{array}{l}\text { Suppression of hepatocyte proliferation, } \\
\text { Retard repair }\end{array}$ & Burr-AW et al. [28] \\
\hline Cholestasis & BDL + Anti-HGF IgG (Mice) & $\begin{array}{l}\text { Suppression of hepatocyte proliferation, } \\
\text { Enhanced liver failure }\end{array}$ & Li-Z et al. [29] \\
\hline \multicolumn{4}{|l|}{ Kidney: } \\
\hline \multirow[t]{2}{*}{$\overline{\text { Ischemic }} \mathrm{ARF}$} & Renal I/R + Anti-HGF IgG (Mice) & $\begin{array}{l}\text { Suppression of tubular epithelial cell } \\
\text { proliferation, }\end{array}$ & Ohnishi-H et al. [47] \\
\hline & & Enhanced apoptosis, Accelerated ARF & Mizuno-S et al. [46] \\
\hline $\begin{array}{l}\text { Obstructive } \\
\text { nephropathy }\end{array}$ & UUO + Anti-HGF IgG (Mice) & $\begin{array}{l}\text { Suppression of tubular epithelial cell } \\
\text { proliferation, Accelerated fibrosis }\end{array}$ & Mizuno-S et al. [45] \\
\hline Nephrotic syndrome & ICGN mouse strain + Anti-HGF IgG & $\begin{array}{l}\text { Suppression of tubular epithelial cell } \\
\text { proliferation, Accelerated fibrosis, } \\
\text { Enhanced TGF- } \beta \text { production }\end{array}$ & Mizuno-S et al. [91] \\
\hline \multicolumn{4}{|l|}{ Lung: } \\
\hline$\overline{\text { Compensatory growth }}$ & Lobectomy + Anti-HGF IgG (Mice) & $\begin{array}{l}\text { Suppression of alveolar and bronchial } \\
\text { proliferation }\end{array}$ & Sakamaki-Y et al. [51] \\
\hline Ischemic injury & Lung I/R + Anti-HGF IgG (Rats) & Suppression of alveolar cell proliferation & Yamada-T et al. $[50]$ \\
\hline \multicolumn{4}{|l|}{ Heart: } \\
\hline$\overline{\text { Myocardial infarction }}$ & Heart I/R + Anti-HGF IgG (Rats) & $\begin{array}{l}\text { Enhanced apoptosis, Accelerated cardiac } \\
\text { failure }\end{array}$ & $\begin{array}{l}\text { Nakamura-T et al. } \\
{[95]}\end{array}$ \\
\hline \multicolumn{4}{|l|}{ Stomach: } \\
\hline$\overline{\text { Gastric erosion }}$ & Cisplatin + Anti-HGF IgG (Mice) & Inhibition of gastric cell proliferation & Nakahira-R et al. [53] \\
\hline \multicolumn{4}{|l|}{ Intestine: } \\
\hline Colitis & $3 \% \mathrm{DSS}+\mathrm{HGF}-\mathrm{A}-\mathrm{KO}$ (Mice) & $\begin{array}{l}\text { Weight loss, Death, Inhibited mucosal } \\
\text { repair }\end{array}$ & Itoh-H et al. [54] \\
\hline \multicolumn{4}{|l|}{ Pancreatic islets: } \\
\hline$\overline{\text { Glucose metabolism }}$ & $\beta$-cell spacific c-Met-KO (Mice) & $\begin{array}{l}\text { Hypoplasia of islets, Decrease in blood } \\
\text { insulin }\end{array}$ & Dai-C et al. $[56]$ \\
\hline \multicolumn{4}{|l|}{ Skin: } \\
\hline Wound healing & $\begin{array}{l}\text { Surgical wound }+ \text { Anti-HGF IgG } \\
\text { (Mice) }\end{array}$ & Retarded repair, Accelerated granuloma & Yoshida-S et al. [57] \\
\hline \multicolumn{4}{|l|}{ Muscles: } \\
\hline Myotitis & Cardiotoxin + uPA-KO (Mice) & $\begin{array}{l}\text { Decrease of regenerating fibers, Enhanced } \\
\text { damage }\end{array}$ & Sisson-TH et al. [59] \\
\hline
\end{tabular}

c-Met-KO, c-Met gene knockout; BDL, Bile duct ligation; I/R, Ischemia and reperfusion; uPA-KO, uPA gene knockout; HGF-A-KO, HGF-activator gene knockout; TGF- $\beta$, Transforming growth factor- $\beta$; DSS, Dextran sodium sulfate. For other abbreviations see text.

\section{HGF as a key mediator of mesenchymal- epithelial interaction for organ development}

During organ development, proper proliferation and morphogenesis of epithelial cells proceeds to form most organs, via inductive interactions with the mesenchyme: organogenesis is initiated when the resident epithelium interacts with specific mesenchy- mal tissues at defined stages of development, resulting in organ-specific structures and functions. Such a pararine loop may provide clues that will allow development of new strategies for regenerative medicine. Thus, it is critical to identify the mesenchymal mediators during organogenesis.

HGF has multiple biological functions, required for generation, development and maturation of 
Table 2. Importance of HGF-c-Met signaling during organ development and maturation

\begin{tabular}{|c|c|c|}
\hline Treatment (Species) & Outcomes & References \\
\hline \multicolumn{3}{|l|}{ Liver: } \\
\hline HGF-KO (Mice) & $\begin{array}{l}\text { Embryonic lethal, Loss of hepatocytes, } \\
\text { Loss of hematopoiesis }\end{array}$ & Schmidt-C et al. Nature 373: 699 (1995) \\
\hline c-Met dominant negative (Xenopus) & Aplasis / Hypoplasia & Aoki-S et al. BBRC 234: 8 (1997) \\
\hline \multicolumn{3}{|l|}{ Kidney: } \\
\hline $\begin{array}{l}\text { Organ culture }+ \text { Anti-HGF IgG } \\
\text { (Mice) }\end{array}$ & $\begin{array}{l}\text { Meta-nephric growth retardation, } \\
\text { Mesenchyme-to-epithelium transition } \\
\text { inhibition }\end{array}$ & Barros-EJ et al. PNAS 92: 4412 (1995) \\
\hline $\begin{array}{l}\text { c-Met dominant negative (Xenopus) } \\
\text { Lung: }\end{array}$ & Pronephron hypoplasia & Aoki-S et al. BBRC 234: 8 (1997) \\
\hline $\begin{array}{l}\text { Organ culture }[\text { E13] + Anti-HGF IgG } \\
\text { (Mice) }\end{array}$ & Inhibition of branching and tubulogenesis & $\begin{array}{l}\text { Ohmichi-H et al. Development 125: } 1315 \\
\text { (1998) }\end{array}$ \\
\hline c-Met-KO [E18.5] (Mice) & Suppression of alveolar formation & Yamamoto-H et al. Dev. Biol. 308: 44 (2007) \\
\hline $\begin{array}{l}\text { Newborn [P3-P6] + Anti-HGF IgG } \\
\text { (Rats) }\end{array}$ & $\begin{array}{l}\text { Inhibition of secondary crest formation, } \\
\text { Loss in alveoli }\end{array}$ & $\begin{array}{l}\text { Padela-S et al. Am. J. Respir. Crit. Care Med. } \\
\text { 172: } 907 \text { (2005) }\end{array}$ \\
\hline \multicolumn{3}{|l|}{ Gut: } \\
\hline $\begin{array}{l}\text { c-Met dominant negative (Xenopus) } \\
\text { Muscle: }\end{array}$ & Aplasia/Hypoplasia & Aoki-S et al. BBRC 234: 8 (1997) \\
\hline $\begin{array}{l}\text { c-Met-KO (Mice) } \\
\text { Nerve tissues: }\end{array}$ & Limb bud hypoplasia, Diaphragm hypoplasia & Bladt-F et al. Nature 376: 768 (1995) \\
\hline $\begin{array}{l}\text { Organ culture }+ \text { anti-HGF IgG } \\
\text { (Rats) }\end{array}$ & Inhibition of motoneuron axon outgrowth & Ebens-A et al. Neuron 17: 1157 (1996) \\
\hline Mu-c-Met-KI (Mice) & $\begin{array}{l}\text { Inhibition of limb innervation, } \\
\text { Defect of spinal cord branching }\end{array}$ & Maina-F et al. Genes Dev. 11: 3341 (1997) \\
\hline $\begin{array}{l}\text { Post-neonate [P3-14] + anti-HGF } \\
\text { IgG (Rats) } \\
\text { Teeth: }\end{array}$ & Inhibition of OPC proliferation, & Ohya-W et al. Brain Res. 1147: 51 (2007) \\
\hline $\begin{array}{l}\text { Organ culture (E14) + HGF-AS } \\
\text { (Mice) }\end{array}$ & Decrease of proliferating enamel epithelium & $\begin{array}{l}\text { Tabata-MJ et al. Development 122: } 1234 \\
\text { (1996) }\end{array}$ \\
\hline \multicolumn{3}{|l|}{ Mammary gland: } \\
\hline HGF-gene transfection (Mice) & $\begin{array}{l}\text { Enhancement of hyperplastic } \\
\text { ductual branching }\end{array}$ & Yant-J et al. Exp. Cell Res. 241: 476 (1998) \\
\hline \multicolumn{3}{|l|}{ Hematopoietic tissue: } \\
\hline$\overline{c-M e t}$ dominant negative (Xenopus) & $\begin{array}{l}\text { Decreased expressions of GATA-1, } \\
\text { SCL and } \alpha \text {-globin }\end{array}$ & Koibuchi-N et al. Blood 103: 3320 (2003) \\
\hline \multicolumn{3}{|l|}{ Placenta: } \\
\hline HGF-KO (Mice) & Trophoblast loss (aplasia) & Uehara-Y et al. Nature 373: 702 (1995) \\
\hline
\end{tabular}

parenchymal organs, as shown in Fig. 1B. HGF is expressed mainly by mesenchymal cells, while c-Met is identified on the parenchyma during organogenesis, ${ }^{20), 65), 66)}$ suggesting that HGF-c-Met signals play an essential role in mammalian and nonmammalian developments. This hypothesis was demonstrated in numerous tissues of rodents or Xenopus (Table 2).
Needless to say, mitogenesis, motogenesis, and "morphogenesis (i.e., 3M-activities) all are essential for organogenesis. HGF was identified as a hepatocyte mitogen, ${ }^{5)}$ and $\mathrm{SF} / \mathrm{HGF}$ was described as a motogen of epithelial cells. ${ }^{13}$ ) Fibroblast-derived condition medium was found in 1991 to induce formation of blanching tubules in epithelial cells (MDCK) in collagen gels; this activity was abolished 
by anti-HGF IgG, identifying HGF as a morphogen. $^{67)}$ The differential selection in 3M-activities was due to a difference in adaptor molecules, which are recruited by tyrosine-phosphorylated c-Met. For example, phosphorylated-tyrosine-dependent recruitment of the Grb-2-SOS complex activates Ras and ERK, leading to migration. ${ }^{22)}$ In contrast, the association and tyrosine phosphorylation of Gab-1, a docking protein that couples c-Met with multiple signaling proteins (such as PI-3K, PLC and Shp-2), leads to morphogenesis and cell movement. ${ }^{68)}$ These variations explain the multi-functional activities of HGF.

Organ development and regeneration may share a common molecular program, especially during morphogenesis. Thus, developmental studies stimulated researchers to determine the role of HGF during migration, proliferation and conversion of stem cells to mature functional cells under diseased conditions. Gaining a better understanding of the HGF-mediated pathways would provide a conceptual bridge between developmental biology and regenerative medicine.

\section{Roles of the HGF-c-Met system during organ diseases}

Since HGF-c-Met system is essential for tissue regeneration in adulthood, we hypothesized that organ failure might occur as a result of either "HGF-deficiency" or "HGF-insufficiency". ${ }^{25), 40)}$ Thus, an understanding of HGF-induced biological functions is helpful for comprehending the mechanism whereby HGF supplementation attenuates lifethreatening disorders. Prior to discussion of the therapeutic effects of HGF, we summarize the multi-faceted functions of HGF that are required for improving organ dysfunction under pathological conditions.

5-1. Anti-apoptotic and function-promoted roles of HGF. Apoptotic events are one of the key pathogenic causes for the manifestation of organ injury. HGF prohibits apoptotic signals via inhibition of caspase-3 activity or induction of anti-apoptotic molecules, such as Bcl-xL. ${ }^{69), 70)}$ Furthermore, HGF prohibits Fas-mediated apoptosis signals via sequestration of Fas and c-Met on cell surfaces. ${ }^{71)}$ These effects of HGF protect the epithelium, neurons and cardiomyocytes during organ diseases (see, section 6). Furthermore, HGF enhances the organspecific functions that are required for maintenance of local metabolism. For instance, HGF enhances albumin synthesis and lipid metabolism in hepato- cytes, ${ }^{72), 73)} \mathrm{Na}^{+}-\mathrm{K}^{+}$-ATPase expression in renal tubules, ${ }^{40)}$ and insulin production in $\beta$-cells. ${ }^{55)}$ These effects lead to both maintenance of homeostasis and functional recovery during diseases.

5-2. Anti-fibrogenic performance of HGF. During chronic organ injuries, TGF- $\beta$ plays a pivotal role in tissue fibrosis via converting HGF-producing fibroblasts to ECM-producing myofibroblasts (MyoFBs). ${ }^{25), 40)}$ HGF inhibits TGF- $\beta$ production in cultures of $\mathrm{MyoFBs}^{74), 75)}$ and intercepts the TGF$\beta 1$-mediated signal pathway by inhibiting nuclear smad2 $/ 3$ activation. ${ }^{76)}$ Moreover, HGF reduced the TGF- $\beta$-receptor ${ }^{77)}$ and induced decorin, an inhibitor of TGF- $\beta 1,{ }^{78)}$ all of which might lead to anti-fibrotic outcomes in vivo (see, section 6.2). In addition, HGF inhibits the functions of other fibrogenic cytokines, including platelet-derived growth factor (PDGF), connective tissue growth factor (CTGF) and monocyte chemoattractant peptide-1 (MCP-1). HGF inhibits PDGF-mediated over-proliferation of MyoFBs, ${ }^{79)}$ reduces CTGF-induced scarring, ${ }^{80)}$ and inhibits MCP-1-mediated inflammation during the HGF-mediated attenuation of fibrosis. HGF induced matrix metalloprotease (MMP) in MyoFBs. ${ }^{81), 82)}$ Induction of MMP by $\mathrm{HGF}$ is required for not only ECM degradation but also for elimination of MyoFBs, both of which contribute to resolution of fibrosis, as discussed later.

5-3. Anti-inflammatory action of HGF toward immune cells. During organ injuries, local or systemic inflammation is a common pathway that leads to tissue destruction. In this process, leucocytes (such as neutrophils, eosinophils and macrophages) are key players in accelerating inflammation. HGF inhibits neutrophil infiltration via the down-regulation of adhesion molecules (such as ICAM-1/E-selectin) on the endothelial cell surface, ${ }^{46)}$ which suppresses ischemia-related injury in various organs. $^{29), 47), 83)}$ Moreover, HGF directly targets activated eosinophils and prohibits their migration via down-regulation of inflammatory mediators during allergic inflammation. ${ }^{84)}$

Activated macrophages elicit inflammatory events via release of pathogenic regulators, such as IL-1, IL-6 and IL-18. HGF suppressed the production of these cytokines via recruitment of antiinflammatory regulators, such as heme oxygenase-1 (HO-1). ${ }^{85)}$ Moreover, HGF stimulated differentiation of macrophages into immunosuppressive dendritic cells (DC), ${ }^{86)}$ which facilitate induction of regulatory T-lymphocytes, a key player in anti-inflammation during immunological challenge. ${ }^{87)}$ Thus, such con- 
certed regulations by HGF may explain the attenuation of immunogenic diseases, as mentioned in section 6-3.

5-4. Angiogenic action of HGF toward vascular cells. Under pathological conditions, hypoxia elicits apoptosis in endothelial and epithelial cells, while a decrease in local vessels further accelerates ischemic organ dysfunction. HGF is an angiogenic factor in vitro, ${ }^{88)}$ in addition to vascular endothelium growth factor (VEGF) and basic fibroblast growth factor (b-FGF). Induction of angiogenesis by HGF supplementation resulted in improved local hypoxia. ${ }^{89)} \mathrm{HGF}$ had an anti-apoptotic effect on endothelium via Bcl-2 induction. ${ }^{70)}$ In contrast to other angiogenic factors, HGF has benefits, such as antithrombosis. ${ }^{90)}$ VEGF enhanced endothelial permeability and edema, whereas HGF inhibited endothelial permeability. ${ }^{46), 90)}$ In contrast to the fibrotic effects of b-FGF, HGF is anti-fibrotic. These benefits lead to "therapeutic angiogenesis", even under hypoxic conditions. ${ }^{89)}$

5-5. Critical part of the intrinsic HGF-c-Met system during chronic organ diseases. Systemic and local HGF levels are increased during chronic diseases, ${ }^{25), 40), 41)}$ but those levels are not higher than in the case of acute diseases. Nevertheless, when an anti-HGF antibody was administered to mice with nephrotic syndrome, tubular injury and renal fibrosis became evident, associated with a reciprocal increase in TGF- $\beta$ levels. ${ }^{91)}$ The similar results were also observed during diabetic nephropathy and hydronephrosis in mice. ${ }^{45), 75)}$ Bile duct ligation (BDL) is known to induce liver fibrosis, and there was an apparent fibrotic lesion post-BDL in the liver after the liver-specific deletion of $c$-Met in mice. ${ }^{92)}$ Thus, we emphasize that the transient increase of HGF is necessary for minimization of tissue fibrosis, while the loss in HGF production allows for tissue dysfunction during chronic diseases.

5-6. Mechanisms for the down-regulation of HGF during persistent injuries. Given that various diseases become severer as a result of HGFdeficiency, how HGF production is impaired is a central interest of pathologists. Under conditions of persistent injury, TGF- $\beta$ and angiotensin-II were shown to suppress HGF gene expression in vitro, ${ }^{25), 89)}$ and the levels of these factors gradually increased in vivo, in response to chronic injury. In addition, hypoxia and hyperglycemia also repressed HGF production both in vitro and in vivo. ${ }^{89), 93)}$ Thus, it is likely that pathogenic factors (i.e., TGF- $\beta$, hypoxia and high-glucose) successfully establish tissue fibrosis via down-regulating HGF production.

In summary, HGF has various actions that counteract pathological events during organ damages. According to the sequence of pathogenic events, each HGF-mediated biological signal is, step-by-step, involved in protection, repair, anti-inflammation and anti-fibrosis. How HGF elicits these activities depends on microenvironment conditions in real-time, such as apoptosis, scarring and ischemia. Such a dynamic change is still of interest to biologists and has led to an understanding of HGF-mediated therapeutic outcomes, as mentioned below.

\section{Therapeutic significance of HGF for the rescue of intractable diseases}

Although the HGF-c-Met axis functions as a self-defense and self-repair system, the increase in HGF production is transient, insufficient and often retarded, resulting in progression of organ failure. Thus, we predicted that re-induction of this repair system by supplementation of HGF might be a strategy to attenuate organ disease. ${ }^{20), 21)}$ This initial hypothesis is now being demonstrated worldwide in animal models of various diseases, in which either recombinant $\mathrm{HGF}$ or the HGF gene is administered, as follows.

6-1. Acute diseases. (1) Fulminant hepatitis: Viral infection of hepatocytes is the major cause of fulminant hepatitis. Activated T-cells eliminate virus-infected hepatocytes via the Fas-mediated pathways to prohibit viral replication, but overelimination of liver cells leads to lethal hepatic failure. A Fas-agonist (Joe2) elicits massive hepatocyte apoptosis in mice that is similar to human fulminant hepatitis. Using this model, we found that HGF prevents a lethal outcome: hepatic destruction became massive within 8 hours post-Joe2-treatment, associated with hepatocyte apoptosis. By contrast, injections of rh-HGF prohibited the onset of hepatic destruction (Fig. 4A). ${ }^{69)}$ In this process, HGF induced Bcl-xL, an anti-apoptotic molecule, in hepatocytes within 2 hours after the Joe2 injection. ${ }^{69)}$ Overall, HGF blocked hepatic apoptosis and failure in the Joe2-treated mice.

(2) Acute renal failure (ARF): ARF is characterized by a rapid loss of renal function and electrolyte abnormalities, which occur due to a defect in tubular integrity, especially around the S3-segments of proximal tubules. Of note, rh-HGF elicits tubular repair and accelerates recovery from renal dysfunction in rodent models of ARF, induced by ischemia, cisplatin or cyclosporine-A.40),44),94) Early injections 
of rh-HGF inhibit the onset of ARF via antiinflammatory effects on renal endothelium. ${ }^{46)}$ In septic mice, HGF markedly attenuated the progression of ARF, via inhibiting systemic inflammation and coagulations, both are critical for septic organ failure. ${ }^{85)}$ As a result, rh-HGF was shown hopeful to decrease the mortality rate during sepsis (Fig. 4B).

(3) Acute lung injury (ALI): Aspiration pneumonia is the most common respiratory complication among elderly humans, and is due to impairments of swallowing and of the cough reflex. In a mouse model of aspiration pneumonia, rh-HGF stimulated DNA synthesis in the airway and alveolar cells. ${ }^{49)}$ Likewise, rh-HGF prevented the onset of ALI, caused by sepsis, ${ }^{85)}$ or by transient ischemia. ${ }^{83)}$ Given that HGF production becomes insufficient in elderly patients, ${ }^{48)}$ HGF-treatment may be reasonable for prevention or reversal of ALI, including pneumonia.

(4) Myocardial infarction (MI): Acute MI is now the leading cause of death in developed countries, and is due to an interruption of the blood supply by atherosclerosis of the coronary vessels. Under hypoxic conditions, the myocardium becomes apoptotic, followed by ventricular dysfunction. We found that rh-HGF targets the myocardium and intercepts apoptotic signals via the induction of Bcl-xL in a rat model of MI. ${ }^{95)}$ As a result, cardiac apoptosis and the loss of ventricular dysfunction were prevented (Fig. 4C). In the same year, Aoki et al. reported that local induction of angiogenesis by HGF cDNA led to improved outcomes during acute MI. ${ }^{96}$ Overall, HGF was found to improve acute MI via myocardial protection and angiogenesis.

6-2. Chronic diseases. (1) Fibrotic diseases: Liver cirrhosis is an irreversible end result of scarring during chronic injury via the loss of hepatocytes, and is associated with a high mortality. HGF is overexpressed by sinusoidal cells at an early stage of alcoholic hepatitis, along with hepatocyte proliferation, but its expression is reduced near fibrotic areas. ${ }^{97)}$ In vitro, $\mathrm{HGF}$ induced $\mathrm{uPA},{ }^{98)}$ which is critical for the degradation of ECM (extra-cellular matrix). Based on this background, we obtained the first evidence that HGF reversed cirrhotic lesions, ${ }^{99)}$ caused by dimethyl nitrosamine (DMN) in rats. In this model, ECM-degrading enzymes were increased by HGF, leading to the disappearance of ECM and hepatocyte repair (Fig. 5A). As a result, HGF improved the lethal outcomes. ${ }^{99)}$ The same effects were seen in other models that differed in the initial cause of cirrhosis. $^{25), 100)}$
Chronic kidney disease (CKD) is incurable, except through renal transplantation. Dialysis market estimates indicate that more than two million patients worldwide have undergone dialysis, and the number of patients with CKD is on the rise. Renal fibrosis represents the morphological equivalent of end-stage CKD. Using mouse models of nephrotic syndrome, we found in 1998 that rh-HGF is useful for restoring renal dysfunction via induction of tubular repair, down-regulation of TGF- $\beta$ production, and resolution of fibrosis (Fig. 5B). ${ }^{101)}$ The same effects were also seen in mouse models of hydoronephrosis and diabetic nephropathy. ${ }^{45), 75)-77)}$

Lung fibrosis is a reflection of interstitial pneumonia. MyoFB hyperplasia leads to over-deposition of ECM, which then impairs alveolar regeneration. This pathological circuit further aggravates lung fibrosis. HGF has anti-fibrotic effects during bleomycin-induced lung injury in mice (Fig. 5C). ${ }^{102)}$ Using the same model, we found that HGF induces apoptosis in MyoFBs via an indirect mechanism: HGF-induced MMP-9 degrades fibronectin, an essential anchor that maintains cell survival. ${ }^{81)}$ As a result, MyoFBs became apoptotic, along with a decrease in the matrix anchors. The enhancing effect of HGF on MyoFB elimination is critical for the resolution of not only lung fibrosis but also of liver cirrhosis ${ }^{82), 103)}$ and arterial sclerosis. ${ }^{104)}$

Growing evidence shows that HGF elicits the regression of fibrosis in numerous organs, such as scleroderma, ${ }^{105)}$ cardiomyopathy, ${ }^{74)}$ vocal scarring and peritoneal fibrosis, in which TGF- $\beta$-induced MyoFBs are critical for tissue scarring. The resolution of fibrosis provides an open space for repair of the epithelium and endothelium, resulting in recovery from organ failure. ${ }^{81)}$

(2) Obstructive diseases: Conservative estimates predict that chronic obstructive pulmonary diseases (COPD), including emphysema, will become the third-leading cause of death by the year 2020 . Emphysema is characterized by the disappearance of alveolar septa, and widespread destruction of the pulmonary vascular beds. Since HGF is a morphogen of alveolar cells ${ }^{49)}$ and endothelial cells, ${ }^{88}$ HGF is expected to attenuate emphysema-related pathological events. ${ }^{106), 107)}$ Shigemura et al. reported that HGF levels in lung tissue and plasma from rats suffering from elastase-induced emphysema increased, and then declined to below basal levels. ${ }^{107)}$ Administration of HGF cDNA to the emphysematous rats resulted in more extensive pulmonary vasculatures and increased proliferation of alveolar 

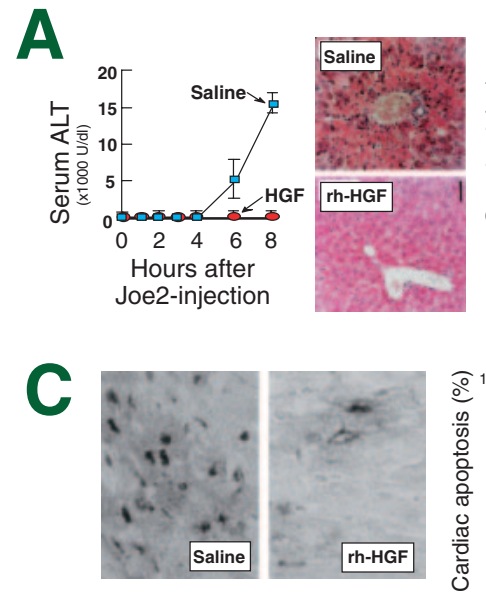
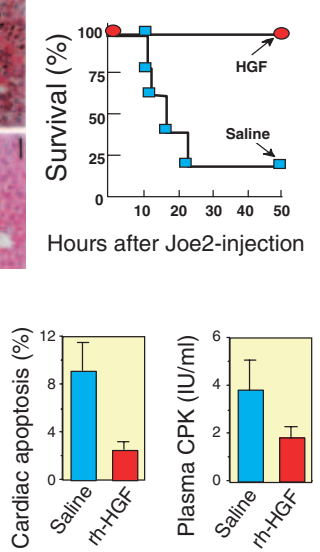

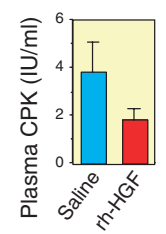

B
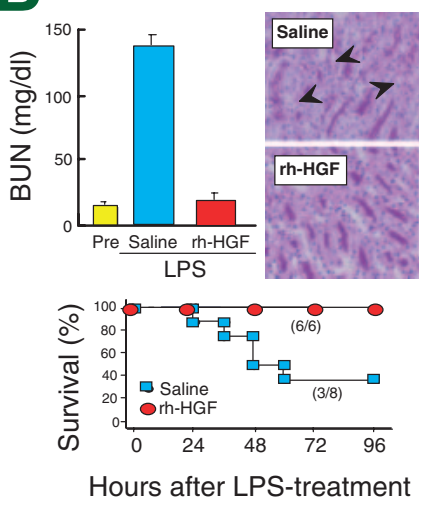

Fig. 4. Therapeutic effects of HGF on acute diseases. (A) Inhibition of the onset of fulminant hepatitis by HGF. Hepatic failure was induced by administration of a Fas-agonist (Joe2) in mice. In this model, HGF almost completely blocked the Joe2-induced hepatic destruction, as estimated by serum ALT (alanine aminotransferase) levels (left) and histological findings (hematoxylin and eosin staining) (middle). Overall, HGF inhibited the lethal outcomes (right). (B) Prevention of septic ARF by HGF-treatment. LPS induced severe renal damage in mice, associated with loss of the apical brush border (arrowheads in PAS staining), while rh-HGF blocked apical damage. Likewise, HGF suppressed the increase in blood urea nitrogen (BUN) levels, which was obvious in the salinetreated septic mice. As a result, HGF-treatment improved the sepsis-related lethal outcome. (C) Preventive effects of HGF on acute MI in rats after transient cardiac ischemia. HGF-treatment inhibited apoptosis of cardiomyocytes, as evaluated by TUNEL staining. Likewise, HGF prevented cardiac destruction, as evidenced by serum CPK (creatinine phosphokinase).

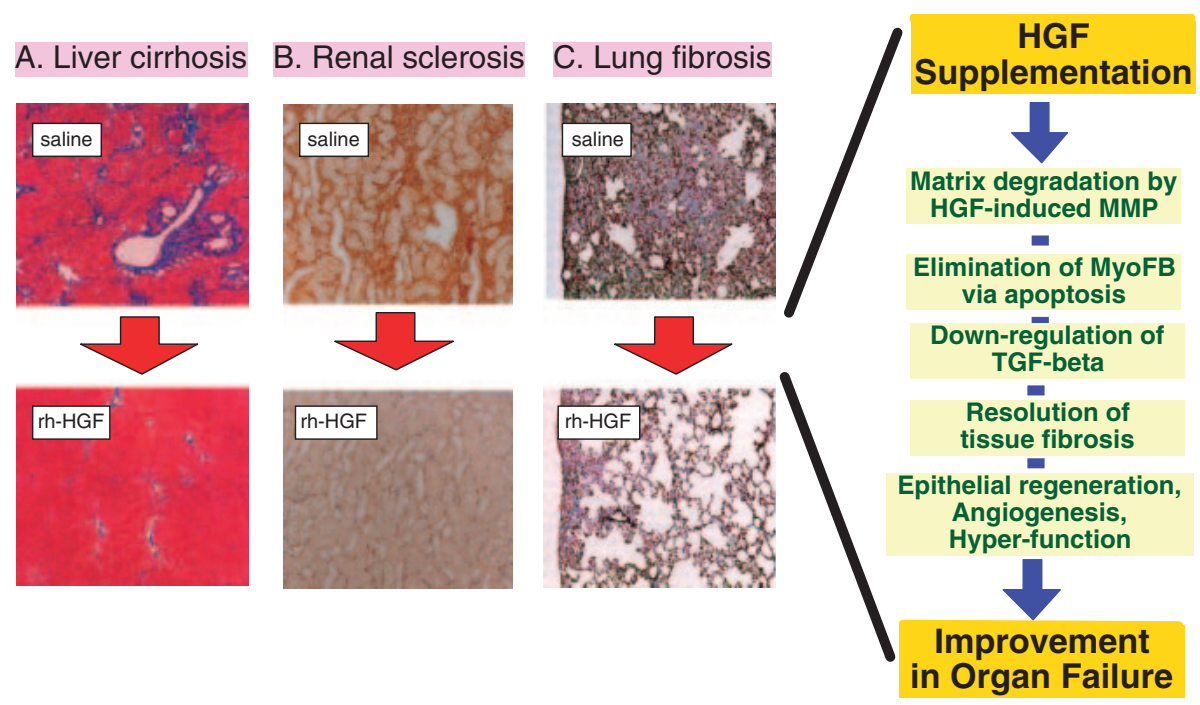

Fig. 5. Effects of HGF on resolution of tissue fibrosis. Therapeutic supplementation with HGF leads to resolution of (A) liver cirrhosis (blue signals in Mason-Trichrome stain), (B) renal sclerosis (brown signals in Type-I collagen stain), (C) lung fibrosis (blue signals in Elastica-Masson stain), cardiomyopathy, scleroderma and so on. During tissue fibrosis, TGF- $\beta$ and MyoFBs are important for ECM accumulation and arrest of regenerative responses. HGF directly targets MyoFBs and induces anoikis-like cell death, through proteolytic degradation of fibronectin by MMPs. Furthermore, HGF down-regulates TGF- $\beta$ production. This MMP-dependent system seems to be reasonable for MyoFB elimination and fibrosis resolution. In response to the regression of fibrotic areas, parenchymal epithelial cells would begin to proliferate, eventually leading to recovery from organ failure.

epithelial cells, which, in turn, improved exercise tolerance and gas exchange. ${ }^{107)}$ Thus, the decrease in local HGF levels is responsible for emphysema, while
HGF supplementation can be an option for treating COPD, associated with induction of alveologenesis and angiogenesis. 

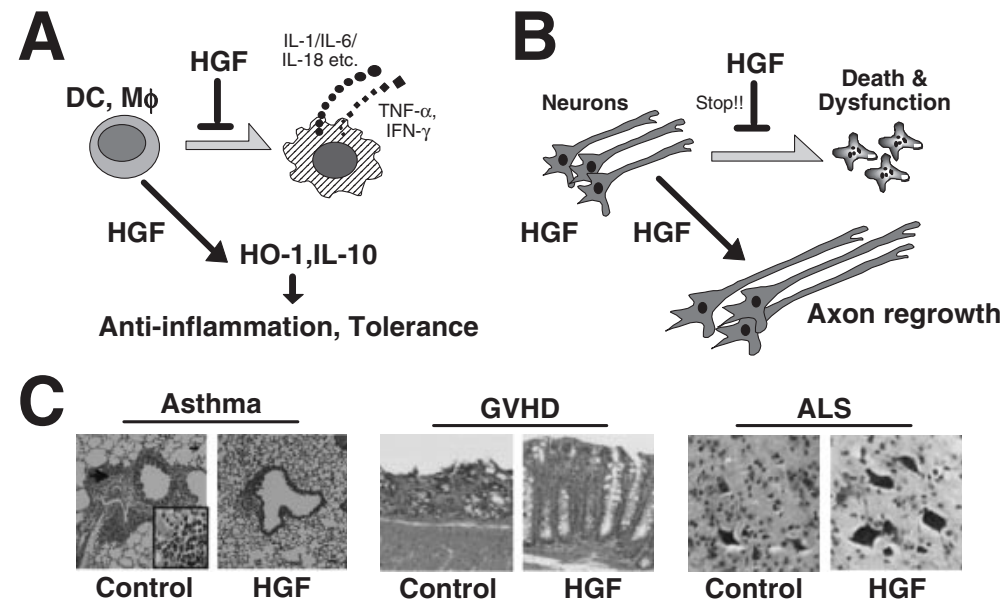

Fig. 6. Anti-inflammatory and neurotrophic actions by HGF for the attenuation of various diseases. (A) Direct effects of HGF on DC or macrophages $(\mathrm{M} \phi)$. HGF inhibits production of inflammatory cytokines, including IL-6, while anti-inflammatory regulators (such as HO-1) are up-regulated, leading to anti-inflammatory outcomes. (B) HGF-induced protective effects on various neurons. These functions are mediated via inhibiting neural cell death, and enhancing neurite outgrowth-axon extensions. (C) Such pleiotropic functions produce therapeutic outcomes in rodents against various diseases. Left: Inhibitions of leukocyte attack by HGF in the lungs after allergic challenges. Middle: Preventive effects of HGF on the mucosal injuries of intestines in mice during GVHD. Right: Maintenance of spinal cord moto-neurons by HGF-transgene in ALS-manifested mice.

Similar results have also been reported in animal models of other obstructive diseases, such as peripheral artery disease (PAD). A decrease in HGF production in the hind limbs due to hypoxia worsened the loss of vascular density and hypoxia, while a local injection of rh-HGF improved hypoxia via induction of angiogenesis in a rabbit model of PAD. ${ }^{89)}$ Under these HGF-insufficient conditions, compensation for the loss of HGF by rh-HGF supplementation improved local hypoxia and dysfunction, via the enhancement of angiogenesis during PAD. ${ }^{89)}$

It is important to note that hypoxia suppresses HGF production, ${ }^{47), 89)}$ while c-Met is over-expressed in response to hypoxia via activation of a transcriptional factor, HIF-1. Thus, obstructive diseases become severe due to hypoxia-induced HGF-deficiency, but its receptor is increased, due to the need for ligand HGF (i.e., SOS sign). This explains the reason why HGF improves obstructive diseaseseven under persistent hypoxia.

6-3. Inflammatory and immunogenic diseases. HGF is critical for tissue protection during inflammatory diseases, via direct action on macrophages, DCs or lymphocytes (i.e., an immunogenic cell-based mechanism) (Fig. 6A). HGF also protects organs from immunogenic challenge via anti-apoptotic effects on epithelial cells (i.e., epitheliumtargeted mechanism), as mentioned above. Both mechanisms lead to therapeutic benefits under inflammatory states, as follows.

(1) Systemic inflammatory response syndrome (SIRS): SIRS occurs during septic infection, leading to the onset of multiple organ dysfunction syndromes (MODS). The progression of MODS is programmed by sequential increases in cytokines, such as IL-1, IL-6 and IL-18 (i.e., the cytokine storm), which are released from the activated macrophages. Using a mouse model of SIRS, we found that rh-HGF targeted macrophages and inhibited the production of IL-1, IL-6 and IL-18. ${ }^{85}$ ) Overall, the onset of MODS was inhibited by HGF. This is the first report to show that HGF acts directly on macrophages to inhibit SIRS, a life-threatening disease.

(2) Asthma: Bronchial asthma is a clinical syndrome associated with allergen-induced airway hyper-responsiveness (AHR), which is characterized by an influx of activated eosinophils and T-lymphocytes. Several cytokines (such as IL-5 and IL-13) play critical roles in orchestrating the allergic response to AHR. Ito et al. demonstrated that HGF attenuates allergen-induced AHR in a mouse model of asthma, ${ }^{84)}$ via suppressing eosinophil and lymphocyte accumulation in the airways. Furthermore, local IL-5 and IL-13 levels were reduced in HGFtreated asthmatic mice. As a result, the increase in lung contractile elements was inhibited by HGFtreatment. ${ }^{108)}$ Thus, HGF may be useful as an 
inhibitor of asthma via suppressing cytokine expression (Fig. 6C).

(3) Immune tolerance after transplantation: The first evaluation of the counter-regulatory role of HGF during immunogenic challenge involved a rat model of renal allograft: ${ }^{109)} 4$-week-injection of rh-HGF led to the acceptance of a renal allograft between two rat strains (F344-to-Lewis), even when co-treatment with cyclosporine-A and rh-HGF was stopped. ${ }^{109)}$ Strikingly, the renal allograft functioned well for $>6$ months with no medical treatment, suggesting that HGF has the potential to induce immune tolerance. Likewise, the inhibition of ischemic injury by rh-HGF resulted in the heart graft acceptance. ${ }^{110)}$ Using mouse models of bone marrow transplantation, Kuroiwa et al. found that HGF is useful for inhibiting graft-versus-host-disease (GVHD) (Fig. 6C). ${ }^{111)}$ In this process, $\mathrm{HGF}$ lowered $\mathrm{TH}_{1}$-cytokines that trigger graft rejection, such as IFN- $\gamma$, while the local levels of $\mathrm{TH}_{2}$-cytokines, including IL-10, were increased. Such a reciprocal regulation may be the key mechanism whereby HGF induces immune tolerance after organ transplantations.

(4) Auto-immune diseases: The next question concerns the direct effect that HGF has on immune cells such as lymphocytes and DCs. Recent studies have addressed this question. Futamatsu et al. found that a myosin-challenge increased the c-Met-positive population of CD4-positive lymphocytes during autoimmune myocarditis. ${ }^{112)}$ When rh-HGF was added to the culture of CD4-positive cells obtained from the diseased rats, myosin-induced proliferation of CD4positive cells was inhibited. Furthermore, HGF increased the levels of IL-4 and IL-10 and decreased IFN- $\gamma$ levels in vitro as well as in vivo. As a result, HGF restored cardiac function in the rat with myocarditis. ${ }^{112)}$ In addition to lymphocytes, HGF also has suppressive effects on DCs. Using a mouse model of rheumatoid disease, Okunishi et al. found that HGF suppressed the production of immunoreactive cytokines, such as IL-17, IL-23 and IFN- $\gamma$ in DCs, leading to the attenuation of rheumatoid arthritis. ${ }^{113)}$ These results suggest that HGF suppresses the over-reaction by immunocytes, possibly via regulation of pathogenic cytokines.

6-4. Neural diseases. Since mature neurons cannot duplicate in response to neural injury, it is important to maintain their survival and stimulate neurite outgrowth in living neurons for attenuating neural diseases. HGF has survival-promoting activity in the neurons of hippocampus, cortex and spinal cords (Fig. 6B). ${ }^{114)-116)}$ Over-expression of HGF-gene prolongs the life span of mice during amyotrophic lateral sclerosis (ALS) via neurotrophic and antiinflammatory mechanisms. ${ }^{116)}$ These studies led to extensive evaluations of HGF to improve various neural diseases, as follows.

(1) Cerebral infarction (CI): CI remains the third-leading cause of death in developed countries. The neuro-protective effects of HGF in vivo were first shown in a gerbil model of acute CI. ${ }^{117)}$ Learning and memory dysfunction were also prevented by early injections of rh-HGF into the brains of microsphereembolized rats. ${ }^{118)}$ However, post-diagnosis treatment is more practical after the onset of CI. Shimamura et al. found that delayed treatment of CI using a local HGF gene transfer led to functional recovery in rats, even under cerebral artery occlusion. ${ }^{119)}$ In this model, HGF enhanced neurite extension, maintained synapses and increased the vessels around the infarct region, thus suggesting the potential of $\mathrm{HGF}$ as a new drug to treat CI.

(2) Neuro-degenerative disease (ND): ND constitutes a set of pathological events originating from slow, irreversible and systematic cell loss within various regions of the brain and the spinal cord. HGF-gene delayed the progression of ALS in mice (Fig. 6C), ${ }^{116)}$ and this effect was reproducible when rh-HGF was locally administered in a rat model of ALS. ${ }^{120)}$ Parkinson's disease is caused by a loss of dopaminergic neurons in the substantia nigra. In a rat model of Parkinson's disease, local HGF gene transfer protected the dopaminergic neurons from a 6-hydroxydopamine (6-OHDA) challenge, followed by the improvement in the rotational asymmetry. ${ }^{121)}$ Furthermore, HGF might be also useful for treatment of Alzheimer's disease. Indeed, Takeuchi et al. found that HGF gene transfer alleviated amyloid- $\beta$ induced cognitive impairment in mice, as evaluated by a behavioral test. ${ }^{122)}$

(3) Spinal cord injury (SCI): SCI is damage to the spinal cord that results in a loss of function such as mobility or feeling. Frequent causes of damage include trauma (car accident, gunshot, etc.) and diseases (polio, spina bifida, Friedreich's ataxia, etc.). Using a rodent model of SCI, Kitamura et al. reported that $\mathrm{HGF}$ gene administration into injured spinal cords promoted neuron and oligodendrocyte survival. ${ }^{123)}$ Furthermore, angiogenesis and axonal re-growth were also accelerated by HGF. Overall, functional recovery was evident in the HGF-treated rats after SCI.

(4) Others: Emerging evidence indicates that HGF promotes the proliferation of neurospheres 
Table 3. Therapeutic effects of recombinant HGF protein or HGF cDNA on intractable diseases

\begin{tabular}{|c|c|c|c|c|}
\hline Target disease & Animal model & HGF-treatment & Outcocmes & References \\
\hline \multicolumn{5}{|l|}{ Liver: } \\
\hline Acute hepatitis & ANIT (Mouse) & rh-HGF, $30 \mu \mathrm{g} /$ mouse, iv & Enhanced regeneration & Ishiki-Y et al. [27] \\
\hline Fluminant hepatitis & $\begin{array}{l}\text { Fas-agonist (Joe2) } \\
\text { (Mouse) }\end{array}$ & rh-HGF, $100 \mu \mathrm{g} /$ mouse, ip & $\begin{array}{l}\text { Inhibition of hepatic failure, } \\
\text { Anti-apoptosis }\end{array}$ & Kosai-K et al. [69] \\
\hline Fatty liver & Ethanol intake (Rat) & $\begin{array}{l}\text { rh-HGF, } 200,800 \mu \mathrm{gg} / \mathrm{kg}, \mathrm{iv}, \\
2 \text { weeks }\end{array}$ & $\begin{array}{l}\text { Anti-lipidosis, Increase in } \\
\text { apolipoprotein-B }\end{array}$ & Tahara-M et al. [73] \\
\hline Liver cirrhosis & $\begin{array}{l}\text { Dimethyl nitrosamine } \\
\text { (Rat) }\end{array}$ & $\begin{array}{l}\text { rh-HGF, } 300 \mu \mathrm{g} / \mathrm{kg}, \mathrm{iv}, \\
4 \text { weeks }\end{array}$ & $\begin{array}{l}\text { Improved survival, Regeneration, } \\
\text { Resolution of chirrhosis }\end{array}$ & Matsuda-Y et al. [99] \\
\hline Liver fibrosis & Bile duct ligation (Rat) & $\begin{array}{l}\text { Naked HGF cDNA, bolus iv } \\
\text { (hydrodynamics) }\end{array}$ & $\begin{array}{l}\text { Attenuation of fibrosis, Inhibited } \\
\text { myofibroblastosis }\end{array}$ & Xia-JL et al. $[100]$ \\
\hline \multicolumn{5}{|l|}{ Kidney: } \\
\hline Acute tubular injury & $\mathrm{HgCl}_{2}$, Cisplatin (Mouse) & $\begin{array}{l}\text { rh-HGF, } 250 \mu \mathrm{g} / \mathrm{kg} \text {, iv, } \\
3 \text { days }\end{array}$ & $\begin{array}{l}\text { Tubular protection and repair, } \\
\text { Improvement in renal dysfunction }\end{array}$ & Kawaida-K et al. [44] \\
\hline Septic acute renal failure & $\begin{array}{l}\text { Lipoporisaccharide } \\
\text { (Mouse) }\end{array}$ & $\mathrm{rh}-\mathrm{HGF}, 500 \mu \mathrm{g} / \mathrm{kg}, \mathrm{sc}$ & $\begin{array}{l}\text { Prevention of cytokine storm, } \\
\text { Improvement in renal dysfunction }\end{array}$ & Kamimoto-M et al. [85] \\
\hline Nephrotic syndrome & $\begin{array}{l}\text { ICGN mouse (tensin- } 2 \\
\text { mutation) }\end{array}$ & $\begin{array}{l}\mathrm{rh}-\mathrm{HGF}, 500 \mu \mathrm{g} / \mathrm{kg}, \mathrm{sc} \text {, } \\
4 \text { weeks }\end{array}$ & $\begin{array}{l}\text { Resolution of fibrosis, Repair, } \\
\text { Improvement in renal failure }\end{array}$ & Mizuno-S et al. [101] \\
\hline Diabetic nephropathy & $\begin{array}{l}\text { Streptozotocin-treated } \\
\text { Mouse }\end{array}$ & $\begin{array}{l}\text { rh-HGF, } 500 \mu \mathrm{g} / \mathrm{kg}, \mathrm{sc} \text {, } \\
4 \text { weeks }\end{array}$ & $\begin{array}{l}\text { Reduced albuminuria, Inhibition of } \\
\text { glomerular injuries }\end{array}$ & Mizuno-S et al. [75] \\
\hline \multicolumn{5}{|l|}{ Lung: } \\
\hline Acute lung injury & Hydrochloric acid (Mouse) & rh-HGF, $10 \mu \mathrm{g} / \mathrm{kg}$, iv, 3 days & Re-alveologenesis, Bronchial repair & Ohmichi-H et al. [49] \\
\hline Pulmonary fibrosis & Bleomycin (Mouse) & $\begin{array}{l}\text { rh-HGF, } 280 \mu \mathrm{g} / \text { mouse, } \\
\text { pump sc, } 14 \text { days }\end{array}$ & Anti-fibrosis, Regeneration & Yaekashiwa-M et al. [102] \\
\hline Pulmonary emphysema & Elastase (Rat) & $\begin{array}{l}\text { HVJ-HGF cDNA, lung } \\
\text { artery injection }\end{array}$ & $\begin{array}{l}\text { Re-alveologenesis, Improvement in } \\
\text { hypo-ventilation }\end{array}$ & Shigemura-N et al. [107] \\
\hline Asthma & Ovalbumin (Mouse) & $\begin{array}{l}\text { rh-HGF, } 500 \mathrm{ug} / \mathrm{kg} \mathrm{sc} \\
3 \text { weeks }\end{array}$ & $\begin{array}{l}\text { Up-regulation of TH2 cytokines, } \\
\text { Anti-allergic effect }\end{array}$ & Ito-W et al. [84] \\
\hline \multicolumn{5}{|l|}{ Heart: } \\
\hline Myocardial infarction & $\begin{array}{l}\text { Ligation and reperfusion } \\
\text { (Rat) }\end{array}$ & rh-HGF, $160 \mu \mathrm{g} / \mathrm{kg}$, iv & $\begin{array}{l}\text { Cardio-protection, Anti-apoptosis, } \\
\text { Improved cardiac function }\end{array}$ & Nakamura-T et al. [95] \\
\hline Cardiomyopathy & Mutant (TO-2 hamster) & $\begin{array}{l}\mathrm{rh}-\mathrm{HGF}, 1 \mathrm{mg} / \mathrm{kg}, \mathrm{sc} \\
3 \text { weeks }\end{array}$ & $\begin{array}{l}\text { Anti-fibrosis, Anti-apoptosis, } \\
\text { Improved cardiac function }\end{array}$ & Nakamura-T et al. $[74]$ \\
\hline Heart transplantation & Allograft (Mouse) & $\begin{array}{l}\text { rh-HGF, } 500 \mu \mathrm{g} / \mathrm{kg}, \mathrm{sc}, \\
2 \text { weeks }\end{array}$ & $\begin{array}{l}\text { Immune tolerance, Anti-fibrosis, } \\
\text { Anti-inflammation }\end{array}$ & Yamaura-K et al. [110] \\
\hline Autoimmune myoarditis & Myosin challenge (Rat) & HVJ-HGF, intra-cardium & $\begin{array}{l}\text { Improvement in cardiac dysfunction, } \\
\text { Anti-inflammation }\end{array}$ & Futamatsu-H et al. [112] \\
\hline \multicolumn{5}{|l|}{ Nervous system: } \\
\hline Brain ischemia & $\begin{array}{l}\text { Transient ischemia } \\
\text { (Gerbil) }\end{array}$ & $\begin{array}{l}\text { rh-HGF, } 10,30 \mu \mathrm{g} / \text { gerbil } \\
\text { (local pump) }\end{array}$ & Inhibition of CA1 neuron death & Miyazawa-T et al. [117] \\
\hline Cerebral infarction & Embolism (Rat) & $\begin{array}{l}\text { rh-HGF, } 30 \mu \mathrm{g} / \text { week } / \mathrm{rat} \\
\text { (local pump) }\end{array}$ & $\begin{array}{l}\text { Improvement in learning and } \\
\text { memory, Anti-apoptosis }\end{array}$ & Date-I et al. [118] \\
\hline Spinal cord injury & Trauma (Rat) & HSV1-HGF cDNA Local & $\begin{array}{l}\text { Improvement in learning and } \\
\text { memory, Anti-apoptosis }\end{array}$ & Kitamura-M et al. [123] \\
\hline ALS & $\begin{array}{l}\mathrm{SOD}(\mathrm{G} 93 \mathrm{~A}) \text {-Transgenic } \\
\text { mouse }\end{array}$ & $\begin{array}{l}\text { HGF-transgene } \\
\text { (Neuron-specific) }\end{array}$ & $\begin{array}{l}\text { Preserved motoneurons, Prolonged } \\
\text { life span }\end{array}$ & Sun-W et al. $[116]$ \\
\hline Parkinson's disease & 6-OHDA (Rat) & Naked HGF cDNA Local & $\begin{array}{l}\text { Preserved dopaminergic neurons, } \\
\text { Improved behavior }\end{array}$ & Koike-H et al. [121] \\
\hline Alzheimer's disease & Amiroid- $\beta$ (Mouse) & Naked HGF cDNA Local & $\begin{array}{l}\text { Improvement in memory, Increased } \\
\text { vessel density }\end{array}$ & Takeuchi-D et al. [122] \\
\hline Hearing impairment & Kanamycin (Rat) & HVJ-HGF cDNA Local & $\begin{array}{l}\text { Improvement in hearing, } \\
\text { Anti-apoptosis }\end{array}$ & Oshima-K et al. [125] \\
\hline \multicolumn{5}{|l|}{ Gastro-intestines: } \\
\hline Stomach ulcer & Cryoplobe injury (Rat) & $\mathrm{rh}-\mathrm{HGF}, 500 \mu \mathrm{g} / \mathrm{kg}$, sc & Enhanced mitosis & Schmassmann-A et al. [52] \\
\hline Host-versus-graft disease & $\begin{array}{l}\text { Bone marrow } \\
\text { transplantation (Mouse) }\end{array}$ & $\begin{array}{l}\text { HVJ-HGF cDNA, im } \\
\text { (endocrine) }\end{array}$ & $\begin{array}{l}\text { Repair, Anti-apoptosis, } \\
\text { Anti-inflammation }\end{array}$ & Kuroiwa-T et al. [111] \\
\hline \multicolumn{5}{|l|}{ Skin: } \\
\hline Hindlimb ischemia & Surgical ligation (Rabbit) & $\begin{array}{l}\mathrm{rh}-\mathrm{HGF}, 500 \mu \mathrm{g} / \mathrm{kg} \text {, arterial } \\
\text { injection }\end{array}$ & $\begin{array}{l}\text { Enhanced angiogenesis, Improved } \\
\text { hypoxia }\end{array}$ & Morishita-R et al. [89] \\
\hline Scleroderma & Bleomycin (Mouse) & $\begin{array}{l}\text { HVJ-HGF cDNA, im } \\
\text { (endocrine) }\end{array}$ & Anti-fibrosis, Anti-inflammation & Wu-MH et al. [105] \\
\hline \multicolumn{5}{|l|}{ Panreas: } \\
\hline Type- 1 diabetes mellitus & Streptozotocin (Mouse) & $\begin{array}{l}\text { Naked HGF cDNA, bolus iv } \\
\text { (hydrodynamics) }\end{array}$ & $\begin{array}{l}\text { Improved hyperglycemia, Prevention } \\
\text { of } \beta \text {-cell destruction }\end{array}$ & Dai-C et al. [55] \\
\hline
\end{tabular}

rh-HGF, recombinant human HGF; ANIT, $\alpha$-naphthylisothiocyanate; HVJ-HGF, hemagglutinating-virus-of-Japan liposome containing HGF cDNA; sc, subcutaneous injection; iv, intravenous injection; ip, intraperitoneal injection. For other abbreviations, see Tables 1, 2 and text. Other indications of HGF supplement therapy are summarized in our current review articles. ${ }^{25), 40), 41)}$ 


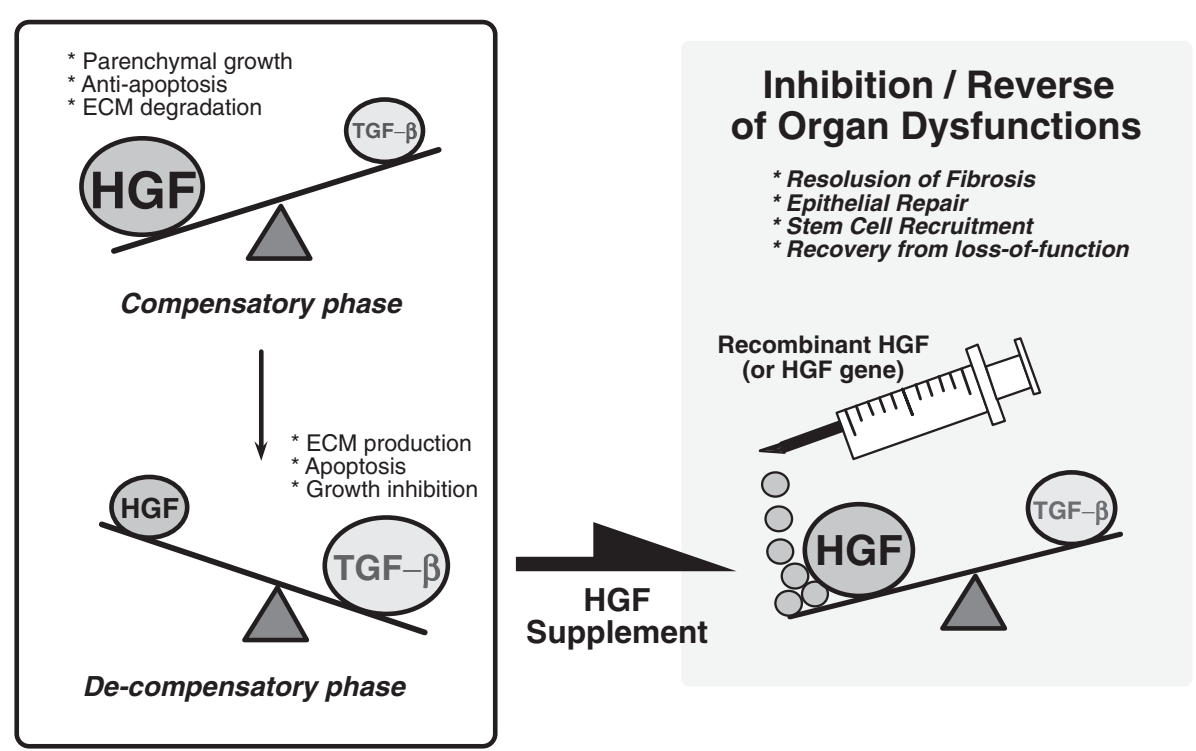

Fig. 7. Pathogenesis and treatment of organ failure by HGF. Reciprocal balance between HGF and TGF- $\beta$ is involved in determining the prognosis of chronic organ diseases, such as liver cirrhosis, renal sclerosis and lung fibrosis. In the early stages of chronic disorders, HGF production is enhanced to suppress TGF- $\beta 1$ production. When HGF dominates the balance, regenerative and anti-fibrotic events occur as a compensatory response. By contrast, TGF- $\beta$ production is up-regulated during the advanced stages to prohibit HGF production. Under TGF- $\beta$-dominant conditions, a loss in regenerative power leads to a rapid progression of organ fibrosis and dysfunction. To reverse the pathogenic balance, HGF supplementation should be considered as a new strategy for the attenuation of fibrosis (and gliosis), a common pathway leading to end-stage organ failure in liver, kidney, lung, heart and possibly the nervous system as well.

and neuronal differentiation of neural stem cells. ${ }^{124)}$ Thus, HGF may induce neurogenesis during neural diseases. In kanamycin-treated deaf rats, delayed administration of HGF cDNA restored hearing loss, the most prevalent sensory deficit in humans. ${ }^{125)}$ HGF also shows promise for attenuating various neural diseases, including diabetic neuropathy ${ }^{126)}$ and multiple sclerosis. ${ }^{87)}$

In summary, HGF improves acute and chronic organ diseases via its regenerative, anti-apoptotic, and anti-fibrotic effects. HGF is useful for attenuating inflammatory disorders via direct effects on immune cells. Moreover, HGF improves neural diseases, associated with the promotion of axon outgrowth and enhancement of neuronal survival. The multiple effects of HGF lead to the attenuation of intractable organ diseases (Table 3).

\section{Summary and perspective}

It has been 21 years since the cloning of human HGF cDNA was successfully performed. ${ }^{10)}$ In the past two decades, the biological functions of the HGF-c-Met axis have been extensively examined, and the crucial physiological and therapeutic roles of stroma-derived HGF have been demonstrated during organogenesis and recovery from diseased conditions. The central focus of physiologists had been on epithelium, myocardium and neurons, since they are functional. On the other hand, cell biologists suggested an important function of stromal cells based on the results of in vitro experiments; actually, fibroblasts were used as a feeder cell to support epithelial cell growth, motility and morphogenesis in vitro. HGF is now known as a key molecule among the stroma-derived mediators. This may be the reason why stroma has a "casting vote" to support homeostasis, although the amount of stroma is much less than that of the parenchyma.

Given that organ failure is defined as "HGFdeficiency" disease, HGF supplementation is reasonable as a pathogenesis-based therapeutic strategy (Fig. 7). The successful cloning of HGF cDNA facilitated the mass-production of recombinant HGF. Indeed, growing evidence indicates that recombinant $\mathrm{HGF}$, or $\mathrm{HGF}$ CDNA, is feasible as a drug to prevent or reverse a variety of diseases. Based on previous experimental outcomes, clinical trials of HGF in patients (phase-I/II) are now ongoing in Japan, the United States and China. For example, a local injection of HGF cDNA-carrying plasmids 
elicited beneficial responses in patients suffering from $\mathrm{PAD}^{127), 128)}$ and cardiac artery diseases (CAD), ${ }^{129)}$ without adverse effects. In addition, rh-HGF has shown promise to attenuate hepatitis and skin ulcers in patients. ${ }^{130), 131)}$ The safety and efficacy of rh-HGF is also being tested in patients with renal diseases.

HGF is also involved in cancer invasion and metastasis. The discovery of NK4 as an HGFantagonist has promoted research in cancer biology, pathology and therapy. ${ }^{132)-134)}$ The mechanism whereby stromal cells over-produce HGF for accelerating tumor malignancy has been investigated, and HGF-inducers (such as autacoids and cytokines) have been identified. Growing evidence indicates that NK4 inhibits tumor growth, invasion and metastasis in rodents bearing various types of malignant tumors. ${ }^{133), 134)}$ It has been shown that over-activation of c-Met, due to either genetic mutation(s) or over-stimulation by HGF, in lung carcinoma elicits resistance to EGF-receptor kinase inhibitors (i.e., Gefinitib), while NK4-therapy alleviated this resistance in rodents, ${ }^{135)}$ suggesting the promising use of NK4 for the rescue of Gefinitibresistant tumors. Overall, NK4-related studies have led to the emerging concept that the HGF-c-Met pathway is a key target for inhibiting tumor malignancy. Several approaches to inhibit HGF-cMet signaling are now being developed as an anticancer agent: using small molecules that inhibit c-Met tyrosine kinase activation, ribozymes, siRNA, anti-HGF IgG, and soluble c-Met. ${ }^{133)}$

Given that HGF is critical for organo-protection, regeneration and tumor malignancy under pathophysiological conditions, we predict that HGF-based molecules, such as HGF-variants, HGF-chimera, HGF-fragments and c-Met-binders show promise as part of a new arsenal in the fight to suppress organ failure and tumor malignancies. Treating these diseases with either HGF or new HGF-based drugs may be more reality than dream.

\section{References}

1) Nakamura, T., Aoyama, K. and Ichihara, A. (1979) Precocious induction of glucokinase in primary cultures of postnatal rat hepatocytes. Biochem. Biophys. Res. Commun. 91, 515-520.

2) Nakamura, T., Shinno, H. and Ichihara, A. (1980) Insulin and glucagon as a new regulator system for tryptophan oxygenase activity demonstrated in primary cultured rat hepatocytes. J. Biol. Chem. 255, 7533-7535.

3) Nakamura, T., Tomita, Y. and Ichihara, A. (1983) Density-dependent growth control of adult rat hepatocytes in primary culture. J. Biochem. 94, $1029-1035$.

4) Forte, T.M. (1984) Primary hepatocytes in monolayer culture: a model for studies on lipoprotein metabolism. Annu. Rev. Physiol. 46, 403-415.

5) Nakamura, T., Nawa, K. and Ichihara, A. (1984) Partial purification and characterization of hepatocyte growth factor from serum of hepatectomized rats. Biochem. Biophys. Res. Commun. 122, $1450-1459$

6) Nakamura, T., Teramoto, H. and Ichihara, A. (1986) Purification and characterization of a growth factor from rat platelets for mature parenchymal hepatocytes in primary cultures. Proc. Natl. Acad. Sci. USA 83, 6489-6493.

7) Nakamura, T., Nawa, K., Ichihara, A., Kaise, N. and Nishino, T. (1987) Purification and subunit structure of hepatocyte growth factor from rat platelets. FEBS Lett. 224, 311-316.

8) Gohda, E., Tsubouchi, H., Nakayama, H., Hirono, S., Sakiyama, O., Takahashi, K. et al. (1988) Purification and partial characterization of hepatocyte growth factor from plasma of a patient with fulminant hepatic failure. J. Clin. Invest. 81, 414-419.

9) Zarnegar, R. and Michalopoulos, G. (1989) Purification and biological characterization of human hepatopoietin A, a polypeptide growth factor for hepatocytes. Cancer Res. 49, 3314-3320.

10) Nakamura, T., Nishizawa, T., Hagiya, M., Seki, T., Shimonishi, M., Sugimura, A. et al. (1989) Molecular cloning and expression of human hepatocyte growth factor. Nature 342, 440-443.

11) Tashiro, K., Hagiya, M., Nishizawa, T., Seki, T., Shimonishi, M., Shimizu, S. et al. (1990) Deduced primary structure of rat hepatocyte growth factor and expression of the mRNA in rat tissues. Proc. Natl. Acad. Sci. USA 87, 3200-3204.

12) Miyazawa, K., Tsubouchi, H., Naka, D., Takahashi, K., Okigaki, M., Arakaki, N. et al. (1989) Molecular cloning and sequence analysis of cDNA for human hepatocyte growth factor. Biochem. Biophys. Res. Commun. 163, 967-973.

13) Stoker, M., Gherardi, E., Perryman, M. and Gray, J. (1987) Scatter factor is a fibroblast-derived modulator of epithelial cell mobility. Nature 327, 239-242.

14) Konishi, T., Takehara, T., Tsuji, T., Ohsato, K., Matsumoto, K. and Nakamura, T. (1991) Scatter factor from human embryonic lung fibroblasts is probably identical to hepatocyte growth factor. Biochem. Biophys. Res. Commun. 180, 765-773.

15) Furlong, R.A., Takehara, T., Taylor, W.G., Nakamura, T. and Rubin, J.S. (1991) Comparison of biological and immunochemical properties indicates that scatter factor and hepatocyte growth factor are indistinguishable. J. Cell Sci. 100, 173-177.

16) Tajima, H., Matsumoto, K. and Nakamura, T. (1991) Hepatocyte growth factor has potent antiproliferative activity in various tumor cell lines. FEBS Lett. 291, 229-232. 
17) Higashio, K., Shima, N., Goto, M., Itagaki, Y., Nagao, M., Yasuda, H. et al. (1990) Identity of a tumor cytotoxic factor from human fibroblasts and hepatocyte growth factor. Biochem. Biophys. Res. Commun. 170, 397-404.

18) Bottaro, D.P., Rubin, J.S., Faletto, D.L., Chan, A.M., Kmiecik, T.E., Vande Woude, G.F. et al. (1991) Identification of the hepatocyte growth factor receptor as the c-met proto-oncogene product. Science 251, 802-804.

19) Higuchi, O., Mizuno, K., Vande Woude, G.F. and Nakamura, T. (1992) Expression of c-met protooncogene in COS cells induces the signal transducing high-affinity receptor for hepatocyte growth factor. FEBS Lett. 301, 282-286.

20) Nakamura, T. (1991) Structure and function of hepatocyte growth factor. Prog. Growth Factor Res. 3, 67-85.

21) Matsumoto, K. and Nakamura, T. (1992) Hepatocyte growth factor: molecular structure, roles in liver regeneration, and other biological functions. Crit. Rev. Oncog. 3, 27-54.

22) Birchmeier, C. and Gherardi, E. (1998) Developmental roles of $\mathrm{HGF} / \mathrm{SF}$ and its receptor, the cMet tyrosine kinase. Trends Cell Biol. 8, 404-410.

23) Fausto, N., Campbell, J.S. and Riehle, K.J. (2006) Liver regeneration. Hepatology 43 (Suppl. 1), S45-S53.

24) Kinoshita, T., Hirao, S., Matsumoto, K. and Nakamura, T. (1991) Possible endocrine control by hepatocyte growth factor of liver regeneration after partial hepatectomy. Biochem. Biophys. Res. Commun. 17, 330-335.

25) Mizuno, S. and Nakamura, T. (2007) Hepatocyte growth factor: a regenerative drug for acute hepatitis and liver cirrhosis. Regen. Med. 2, 161170.

26) Yanagita, K., Nagaike, M., Ishibashi, H., Niho, Y., Matsumoto, K. and Nakamura, T. (1992) Lung may have an endocrine function producing hepatocyte growth factor in response to injury of distal organs. Biochem. Biophys. Res. Commun. 182, 802-809.

27) Ishiki, Y., Ohnishi, H., Muto, Y., Matsumoto, K. and Nakamura, T. (1992) Direct evidence that hepatocyte growth factor is a hepatotrophic factor for liver regeneration and has a potent antihepatitis effect in vivo. Hepatology 16, 1227-1235.

28) Burr, A.W., Toole, K., Chapman, C., Hines, J.E. and Burt, A.D. (1998) Anti-hepatocyte growth factor antibody inhibits hepatocyte proliferation during liver regeneration. J. Pathol. 185, 298302.

29) Li, Z., Mizuno, S. and Nakamura, T. (2007) Antinecrotic and antiapoptotic effects of hepatocyte growth factor on cholestatic hepatitis in a mouse model of bile-obstructive diseases. Am. J. Physiol. Gastrointest. Liver Physiol. 292, G639G646.

30) Huh, C.G., Factor, V.M., Sanchez, A., Uchida, K., Conner, E.A. and Thorgeisson, S.S. (2004) Hepatocyte growth factor/c-Met signaling pathway is required for efficient liver regeneration and repair. Proc. Natl. Acad. Sci. USA 101, 4477-4482.

31) Kinoshita, T., Tashiro, K. and Nakamura, T. (1989) Marked increase of HGF mRNA in non-parenchymal liver cells of rats treated with hepatotoxins. Biochem. Biophys. Res. Commun. 165, 1229-1234.

32) Noji, S., Tashiro, K., Koyama, E., Nohno, T., Ohyama, K., Taniguchi, S. et al. (1990) Expression of hepatocyte growth factor gene in endothelial and Kupffer cells of damaged rat livers, as revealed by in situ hybridization. Biochem. Biophys. Res. Commun. 173, 42-47.

33) Khan, K.N., Masuzaki, H., Fujishita, A., Kitajima, M., Hiraki, K., Sekine, I. et al. (2005) Interleukin6 - and tumour necrosis factor $\alpha$-mediated expression of hepatocyte growth factor by stromal cells and its involvement in the growth of endometriosis. Hum. Reprod. 20, 2715-2723.

34) Ekberg, S., Luther, M., Nakamura, T. and Jansson, J.O. (1992) Growth hormone promotes early initiation of hepatocyte growth factor gene expression in the liver of hypophysectomized rats after partial hepatectomy. J. Endocrinol. 135, 5967.

35) Broten, J., Michalopoulos, G., Petersen, B. and Cruise, J. (1999) Adrenergic stimulation of hepatocyte growth factor expression. Biochem. Biophys. Res. Commun. 262, 76-79.

36) Matsumoto, K., Okazaki, H. and Nakamura, T. (1995) Novel function of prostaglandins as inducers of gene expression of HGF and putative mediators of tissue regeneration. J. Biochem. 117, 458-464.

37) Matsumoto, K., Tajima, H., Hamanoue, M., Kohno, S., Kinoshita, T. and Nakamura, T. (1992) Identification and characterization of "injurin," an inducer of expression of the gene for hepatocyte growth factor. Proc. Natl. Acad. Sci. USA 89, 3800-3804.

38) Tajima, H., Higuchi, O., Mizuno, K. and Nakamura, T. (1992) Tissue distribution of hepatocyte growth factor receptor and its exclusive downregulation in a regenerating organ after injury. $\mathrm{J}$. Biochem. 111, 401-406.

39) Hashigasako, A., Machide, M., Nakamura, T., Matsumoto, K. and Nakamuram, T. (2004) Bidirectional regulation of Ser-985 phosphorylation of c-met via protein kinase $\mathrm{C}$ and protein phosphatase $2 \mathrm{~A}$ involves c-Met activation and cellular responsiveness to hepatocyte growth factor. J. Biol. Chem. 279, 26445-26452.

40) Mizuno, S., Matsumoto, K. and Nakamura, T. (2008) HGF as a renotrophic and anti-fibrotic regulator in chronic renal disease. Front. Biosci. 13, 7072-7086.

41) Funakoshi, H. and Nakamura, T. (2003) Hepatocyte growth factor: from diagnosis to clinical applications. Clin. Chim. Acta 327, 1-23.

42) Nagaike, M., Hirao, S., Tajima, H., Noji, S., Taniguchi, S., Matsumoto, K. et al. (1991) Renotropic functions of hepatocyte growth factor 
in renal regeneration after unilateral nephrectomy. J. Biol. Chem. 266, 22781-22784.

43) Igawa, T., Matsumoto, K., Kanda, S., Saito, Y. and Nakamura, T. (1993) Hepatocyte growth factor may function as a renotropic factor for regeneration in rats with acute renal injury. Am. J. Physiol. 265, F61-F69.

44) Kawaida, K., Matsumoto, K., Shimazu, H. and Nakamura, T. (1994) Hepatocyte growth factor prevents acute renal failure and accelerates renal regeneration in mice. Proc. Natl. Acad. Sci. USA 91, 4357-4361.

45) Mizuno, S., Matsumoto, K. and Nakamura, T. (2001) Hepatocyte growth factor suppresses interstitial fibrosis in a mouse model of obstructive nephropathy. Kidney Int. 59, 1304-1314.

46) Mizuno, S. and Nakamura, T. (2005) Prevention of neutrophil extravasation by hepatocyte growth factor leads to attenuations of tubular apoptosis and renal dysfunction in mouse ischemic kidneys. Am. J. Pathol. 166, 1895-1905.

47) Ohnishi, H., Mizuno, S. and Nakamura, T. (2008) Inhibition of tubular cell proliferation by neutralizing endogenous HGF leads to renal hypoxia and bone marrow-derived cell engraftment in acute renal failure. Am. J. Physiol. Renal Physiol. 294, F326-F335.

48) Yanagita, K., Matsumoto, K., Sekiguchi, K., Ishibashi, H., Niho, Y. and Nakamura, T. (1993) Hepatocyte growth factor may act as a pulmotrophic factor on lung regeneration after acute lung injury. J. Biol. Chem. 268, 21212-21217.

49) Ohmichi, H., Matsumoto, K. and Nakamura, T. (1996) In vivo mitogenic action of HGF on lung epithelial cells: pulmotrophic role in lung regeneration. Am. J. Physiol. 270, L1031-L1039.

50) Yamada, T., Hisanaga, M., Nakajima, Y., Mizuno, S., Matsumoto, K., Nakamura, T. et al. (2000) Enhanced expression of hepatocyte growth factor by pulmonary ischemia-reperfusion injury in the rat. Am. J. Respir. Crit. Care Med. 162, 707-715.

51) Sakamaki, Y., Matsumoto, K., Mizuno, S., Miyoshi, S., Matsuda, H. and Nakamura, T. (2002) Hepatocyte growth factor stimulates proliferation of respiratory epithelial cells during pneumonectomy compensatory lung growth in mice. Am. J. Respir. Cell Mol. Biol. 26, 525-533.

52) Schmassmann, A., Stettler, C., Poulsom, R., Tarasova, N., Hirschi, C., Flogerzi, B. et al. (1997) Roles of hepatocyte growth factor and its receptor Met during gastric ulcer healing in rats. Gastroenterology 113, 1858-1872.

53) Nakahira, R., Mizuno, S., Yoshimine, T. and Nakamura, T. (2006) The loss of local HGF, an endogenous gastrotrophic factor, leads to mucosal injuries in the stomach of mice. Biochem. Biophys. Res. Commun. 341, 897-903.

54) Itoh, H., Naganuma, S., Takeda, N., Miyata, S., Uchinokura, S., Fukushima, T. et al. (2004) Regeneration of injured intestinal mucosa is impaired in hepatocyte growth factor activator deficient mice. Gastroenterology 127, 1423-1435.
55) Dai, C., Li, Y., Yang, J. and Liu, Y. (2003) Hepatocyte growth factor preserves beta cell mass and mitigates hyperglycemia in streptozotocininduced diabetic mice. J. Biol. Chem. 278, 2708027087.

56) Dai, C., Huh, C.G., Thorgeirsson, S.S. and Liu, Y. (2005) Beta-cell-specific ablation of the hepatocyte growth factor receptor results in reduced islet size, impaired insulin secretion, and glucose intolerance. Am. J. Pathol. 167, 429-436.

57) Yoshida, S., Yamaguchi, Y., Itami, S., Yoshikawa, K., Tabata, Y., Matsumoto, K. et al. (2003) Neutralization of hepatocyte growth factor leads to retarded cutaneous wound healing associated with decreased neovascularization and granulation tissue formation. J. Invest. Dermatol. 120, 335-343.

58) Lindner, G., Menrad, A., Gherardi, E., Merlino, G., Welker, P., Handjiski, B. et al. (2000) Involvement of hepatocyte growth factor/scatter factor and met receptor signaling in hair follicle morphogenesis and cycling. FASEB J. 14, 319-332.

59) Sisson, T.H., Nguyen, M.H., Yu, B., Novak, M.L., Simon, R.H. and Koh, T.J. (2009) Urokinase-type plasminogen activator increases hepatocyte growth factor activity required for skeletal muscle regeneration. Blood 114, 5052-5061.

60) Wakitani, S., Imoto, K., Kimura, T., Ochi, T., Matsumoto, K. and Nakamura, T. (1997) Hepatocyte growth factor facilitates cartilage repair. Full thickness articular cartilage defect studied in rabbit knees. Acta Orthop. Scand. 68, 474-480.

61) Mizuno, K., Higuchi, O., Ihle, J.N. and Nakamura, T. (1993) Hepatocyte growth factor stimulates growth of hematopoietic progenitor cells. Biochem. Biophys. Res. Commun. 194, 178-186.

62) Takai, K., Hara, J., Matsumoto, K., Hosoi, G., Osugi, Y., Tawa, A. et al. (1997) Hepatocyte growth factor is constitutively produced by human bone marrow stromal cells and indirectly promotes hematopoiesis. Blood 89, 1560-1565.

63) Kosone, T., Takagi, H., Horiguchi, N., Toyoda, M., Sohara, N., Kakizaki, S. et al. (2007) Hepatocyte growth factor accelerates thrombopoiesis in transgenic mice. Lab. Invest. 87, 284-291.

64) Schmidt, C., Bladt, F., Goedecke, S., Brinkmann, V., Zschiesche, W., Sharpe, M. et al. (1995) Scatter factor/hepatocyte growth factor is essential for liver development. Nature 373, 699-702.

65) Barros, E.J., Santos, O.F., Matsumoto, K. Nakamura, T. and Nigam, S.K. (1995) Differential tubulogenic and branching morphogenetic activities of growth factors: implications for epithelial tissue development. Proc. Natl. Acad. Sci. USA 92, 4412-4416.

66) Ohmichi, H., Koshimizu, U., Matsumoto, K. and Nakamura, T. (1998) Hepatocyte growth factor (HGF) acts as a mesenchyme-derived morphogenic factor during fetal lung development. Development 125, 1315-1324.

67) Montesano, R., Matsumoto, K., Nakamura, T. and Orci, L. (1991) Identification of a fibroblast- 
derived epithelial morphogen as hepatocyte growth factor. Cell 67, 901-908.

68) Schaeper, U., Gehring, N.H., Fuchs, K.P., Sachs, M., Kempkes, B. and Birchmeier, W. (2000) Coupling of Gab1 to c-Met, Grb2, and Shp2 mediates biological responses. J. Cell Biol. 149, 1419-1432.

69) Kosai, K., Matsumoto, K., Nagata, S., Tsujimoto, Y. and Nakamura, T. (1998) Abrogation of Fasinduced fulminant hepatic failure in mice by hepatocyte growth factor. Biochem. Biophys. Res. Commun. 244, 683-690.

70) Yamamoto, K., Morishita, R., Hayashi, S., Matsushita, H., Nakagami, H., Moriguchi, A. et al. (2001) Contribution of Bcl-2, but not Bcl-xL and Bax, to antiapoptotic actions of hepatocyte growth factor in hypoxia-conditioned human endothelial cells. Hypertension 37, 1341-1348.

71) Wang, X., DeFrances, M.C., Dai, Y., Pediaditakis, P., Johnson, C., Bell, A. et al. (2002) A mechanism of cell survival: sequestration of Fas by the HGF receptor Met. Mol. Cell 9, 411-421.

72) Takehara, T., Matsumoto, K. and Nakamura, T. (1992) Cell density-dependent regulation of albumin synthesis and DNA synthesis in rat hepatocytes by hepatocyte growth factor. J. Biochem. 112, 330-334.

73) Tahara, M., Matsumoto, K., Nukiwa, T. and Nakamura, T. (1999) Hepatocyte growth factor leads to recovery from alcohol-induced fatty liver in rats. J. Clin. Invest. 103, 313-320.

74) Nakamura, T., Matsumoto, K., Mizuno, S., Sawa, Y., Matsuda, H. and Nakamura, T. (2005) Hepatocyte growth factor prevents tissue fibrosis, remodeling, and dysfunction in cardiomyopathic hamster hearts. Am. J. Physiol. Heart Circ. Physiol. 288, H2131-H2139.

75) Mizuno, S. and Nakamura, T. (2004) Suppressions of chronic glomerular injuries and TGF- $\beta_{1}$ production by HGF in attenuation of murine diabetic nephropathy. Am. J. Physiol. Renal Physiol. 286, F134-F143.

76) Dai, C. and Liu, Y. (2004) Hepatocyte growth factor antagonizes the profibrotic action of TGF- $\beta 1$ in mesangial cells by stabilizing Smad transcriptional corepressor TGIF. J. Am. Soc. Nephrol. 15, $1402-1412$.

77) Yang, J. and Liu, Y. (2002) Blockage of tubular epithelial to myofibroblast transition by hepatocyte growth factor prevents renal interstitial fibrosis. J. Am. Soc. Nephrol. 13, 96-107.

78) Kobayashi, E., Sasamura, H., Mifune, M., ShimizuHirota, R., Kuroda, M., Hayashi, M. et al. (2003) Hepatocyte growth factor regulates proteoglycan synthesis in interstitial fibroblasts. Kidney Int. 64, 1179-1188.

79) Bessho, K., Mizuno, S., Matsumoto, K. and Nakamura, T. (2003) Counteractive effects of HGF on PDGF-induced mesangial cell proliferation in a rat model of glomerulonephritis. Am. J. Physiol. Renal Physiol. 284, F1171-F1180.

80) Inoue, T., Okada, H., Kobayashi, T., Watanabe, Y.,
Kanno, Y., Kopp, J.B. et al. (2003) Hepatocyte growth factor counteracts transforming growth factor- $\beta_{1}$, through attenuation of connective tissue growth factor induction, and prevents renal fibrogenesis in $5 / 6$ nephrectomized mice. FASEB J. 17, 268-270.

81) Mizuno, S., Matsumoto, K., Li, M.Y. and Nakamura, T. (2005) HGF reduces advancing lung fibrosis in mice: a potential role for MMPdependent myofibroblast apoptosis. FASEB J. 19, 580-582.

82) Kim, W.H., Matsumoto, K., Bessho, K. and Nakamura, T. (2005) Growth inhibition and apoptosis in liver myofibroblasts promoted by hepatocyte growth factor leads to resolution from liver cirrhosis. Am. J. Pathol. 166, 1017-1028.

83) Makiuchi, A., Yamaura, K., Mizuno, S., Matsumoto, K., Nakamura, T., Amano, J. et al. (2007) Hepatocyte growth factor prevents pulmonary ischemia-reperfusion injury in mice. J. Heart Lung Transplant. 26, 935-943.

84) Ito, W., Kanehiro, A., Matsumoto, K., Hirano, A., Ono, K., Maruyama, H. et al. (2005) Hepatocyte growth factor attenuates airway hyperresponsiveness, inflammation, and remodeling. Am. J. Respir. Cell Mol. Biol. 32, 268-280.

85) Kamimoto, M., Mizuno, S., Matsumoto, K. and Nakamura, T. (2009) Hepatocyte growth factor prevents multiple organ injuries in endotoxemic mice through a heme oxygenase-1-dependent mechanism. Biochem. Biophys. Res. Commun. 380, 333-337.

86) Rutella, S., Bonanno, G., Procoli, A., Mariotti, A., de Ritis, D.G., Curti, A. et al. (2006) Hepatocyte growth factor favors monocyte differentiation into regulatory interleukin (IL)- $10^{++}$IL- $12^{\text {low } / \text { neg }}$ accessory cells with dendritic-cell features. Blood 108, 218-227.

87) Benkhoucha, M., Santiago-Raber, M.L., Schneiter, G., Chofflon, M., Funakoshi, H., Nakamura, T. et al. (2010) Hepatocyte growth factor inhibits CNS autoimmunity by inducing tolerogenic dendritic cells and CD25 ${ }^{+}$Foxp $3^{+}$regulatory $\mathrm{T}$ cells. Proc. Natl. Acad. Sci. USA 107, 6424-6429.

88) Nakamura, Y., Morishita, R., Higaki, J., Kida, I., Aoki, M., Moriguchi, A. et al. (1996) Hepatocyte growth factor is a novel member of the endothelium-specific growth factors: additive stimulatory effect of hepatocyte growth factor with basic fibroblast growth factor but not with vascular endothelial growth factor. J. Hypertens. 14, 10671072 .

89) Morishita, R., Nakamura, S., Hayashi, S., Taniyama, Y., Moriguchi, A., Nagano, T. et al. (1999) Therapeutic angiogenesis induced by human recombinant hepatocyte growth factor in rabbit hind limb ischemia model as cytokine supplement therapy. Hypertension 33, 1379-1384.

90) Birukova, A.A., Alekseeva, E., Mikaelyan, A. and Birukov, K.G. (2007) HGF attenuates thrombininduced endothelial permeability by Tiam1-mediated activation of the Rac pathway and by 
Tiam1/Rac-dependent inhibition of the Rho pathway. FASEB J. 21, 2776-2786.

91) Mizuno, S., Matsumoto, K., Kurosawa, T., MizunoHorikawa, Y. and Nakamura, T. (2000) Reciprocal balance of hepatocyte growth factor and transforming growth factor- $\beta 1$ in renal fibrosis in mice. Kidney Int. 57, 937-948.

92) Giebeler, A., Boekschoten, M.V., Klein, C., Borowiak, M., Birchmeier, C., Gassler, N. et al. (2009) c-Met confers protection against chronic liver tissue damage and fibrosis progression after bile duct ligation in mice. Gastroenterology 137, 297-308.

93) Morishita, R., Nakamura, S., Nakamura, Y., Aoki, M., Moriguchi, A., Kida, I. et al. (1997) Potential role of an endothelium-specific growth factor, hepatocyte growth factor, on endothelial damage in diabetes. Diabetes 46, 138-142.

94) Miller, S.B., Martin, D.R., Kissane, J. and Hammerman, M.R. (1994) Hepatocyte growth factor accelerates recovery from acute ischemic renal injury in rats. Am. J. Physiol. 266, F129F134.

95) Nakamura, T., Mizuno, S., Matsumoto, K., Sawa, Y., Matsuda, H. and Nakamura, T. (2000) Myocardial protection from ischemia/reperfusion injury by endogenous and exogenous HGF. J. Clin. Invest. 106, 1511-1519.

96) Aoki, M., Morishita, R., Taniyama, Y., Kida, I., Moriguchi, A., Matsumoto, K. et al. (2000) Angiogenesis induced by hepatocyte growth factor in non-infarcted myocardium and infarcted myocardium: up-regulation of essential transcription factor for angiogenesis, ets. Gene Ther. 7, 417-427.

97) Fang, J.W., Bird, G.L., Nakamura, T., Davis, G.L. and Lau, J.Y. (1994) Hepatocyte proliferation as an indicator of outcome in acute alcoholic hepatitis. Lancet 343, 820-823.

98) Pepper, M.S., Matsumoto, K., Nakamura, T., Orci, L. and Montesano, R. (1992) Hepatocyte growth factor increases urokinase-type plasminogen activator (u-PA) and u-PA receptor expression in Madin-Darby canine kidney epithelial cells. J. Biol. Chem. 267, 20493-20496.

99) Matsuda, Y., Matsumoto, K., Ichida, T. and Nakamura, T. (1995) Hepatocyte growth factor suppresses the onset of liver cirrhosis and abrogates lethal hepatic dysfunction in rats. J. Biochem. 118, 643-649.

100) Xia, J.L., Dai, C., Michalopoulos, G.K. and Liu, Y. (2006) Hepatocyte growth factor attenuates liver fibrosis induced by bile duct ligation. Am. J. Pathol. 168, 1500-1512.

101) Mizuno, S., Kurosawa, T., Matsumoto, K., MizunoHorikawa, Y., Okamoto, M. and Nakamura, T. (1998) Hepatocyte growth factor prevents renal fibrosis and dysfunction in a mouse model of chronic renal disease. J. Clin. Invest. 101, $1827-$ 1834.

102) Yaekashiwa, M., Nakayama, S., Ohnuma, K., Sakai, T., Abe, T., Satoh, K. et al. (1997) Simultaneous or delayed administration of hepatocyte growth factor equally represses the fibrotic changes in murine lung injury induced by bleomycin. A morphologic study. Am. J. Respir. Crit. Care Med. 156, 1937-1944.

103) Ueki, T., Kaneda, Y., Tsutsui, H., Nakanishi, K., Sawa, Y., Morishita, R. et al. (1999) Hepatocyte growth factor gene therapy of liver cirrhosis in rats. Nat. Med. 5, 226-230.

104) Ono, M., Sawa, Y., Mizuno, S., Fukushima, N., Ichikawa, H., Bessho, K. et al. (2004) Hepatocyte growth factor suppresses vascular medial hyperplasia and matrix accumulation in advanced pulmonary hypertension of rats. Circulation 110, 2896-2902.

105) Wu, M.H., Yokozeki, H., Takagawa, S., Yamamoto, T., Satoh, T., Kaneda, Y. et al. (2004) Hepatocyte growth factor both prevents and ameliorates the symptoms of dermal sclerosis in a mouse model of scleroderma. Gene Ther. 11, 170-180.

106) Ishizawa, K., Kubo, H., Yamada, M., Kobayashi, S., Suzuki, T., Mizuno, S. et al. (2004) Hepatocyte growth factor induces angiogenesis in injured lungs through mobilizing endothelial progenitor cells. Biochem. Biophys. Res. Commun. 324, 276280.

107) Shigemura, N., Sawa, Y., Mizuno, S., Ono, M., Ohta, M., Nakamura, T. et al. (2005) Amelioration of pulmonary emphysema by in vivo gene transfection with hepatocyte growth factor in rats. Circulation 111, 1407-1414.

108) Okunishi, K., Dohi, M., Nakagome, K., Tanaka, R., Mizuno, S., Matsumoto, K. et al. (2005) A novel role of hepatocyte growth factor as an immune regulator through suppressing dendritic cell function. J. Immunol. 175, 4745-4753.

109) Azuma, H., Takahara, S., Matsumoto, K., Ichimaru, N., Wang, J.D., Moriyama, T. et al. (2001) Hepatocyte growth factor prevents the development of chronic allograft nephropathy in rats. J. Am. Soc. Nephrol. 12, 1280-1292.

110) Yamaura, K., Ito, K., Tsukioka, K., Wada, Y., Makiuchi, A., Sakaguchi, M. et al. (2004) Suppression of acute and chronic rejection by hepatocyte growth factor in a murine model of cardiac transplantation: induction of tolerance and prevention of cardiac allograft vasculopathy. Circulation 110, 1650-1657.

111) Kuroiwa, T., Kakishita, E., Hamano, T., Kataoka, Y., Seto, Y., Iwata, N. et al. (2001) Hepatocyte growth factor ameliorates acute graft-versus-host disease and promotes hematopoietic function. J. Clin. Invest. 107, 1365-1373.

112) Futamatsu, H., Suzuki, J., Mizuno, S., Koga, N., Adachi, S., Kosuge, H. et al. (2005) Hepatocyte growth factor ameliorates the progression of experimental autoimmune myocarditis: a potential role for induction of $\mathrm{T}$ helper 2 cytokines. Circ. Res. 96, 823-830.

113) Okunishi, K., Dohi, M., Fujio, K., Nakagome, K., Tabata, Y., Okasora, T. et al. (2007) Hepatocyte growth factor significantly suppresses collagen- 
induced arthritis in mice. J. Immunol. 179, 55045513.

114) Honda, S., Kagoshima, M., Wanaka, A., Tohyama, M., Matsumoto, K. and Nakamura, T. (1995) Localization and functional coupling of HGF and c-Met/HGF receptor in rat brain: implication as neurotrophic factor. Brain Res. Mol. Brain Res. 32, 197-210.

115) Hamanoue, M., Takemoto, N., Matsumoto, K., Nakamura, T., Nakajima, K. and Kohsaka, S. (1996) Neurotrophic effect of hepatocyte growth factor on central nervous system neurons in vitro. J. Neurosci. Res. 43, 554-564.

116) Sun, W., Funakoshi, H. and Nakamura, T. (2002) Overexpression of HGF retards disease progression and prolongs life span in a transgenic mouse model of ALS. J. Neurosci. 22, 6537-6548.

117) Miyazawa, T., Matsumoto, K., Ohmichi, H., Katoh, H., Yamashima, T. and Nakamura, T. (1998) Protection of hippocampal neurons from ischemiainduced delayed neuronal death by hepatocyte growth factor: a novel neurotrophic factor. J. Cereb. Blood Flow Metab. 18, 345-348.

118) Date, I., Takagi, N., Takagi, K., Kago, T., Matsumoto, K., Nakamura, T. et al. (2004) Hepatocyte growth factor improved learning and memory dysfunction of microsphere-embolized rats. J. Neurosci. Res. 78, 442-453.

119) Shimamura, M., Sato, N., Waguri, S., Uchiyama, Y., Hayashi, T., Iida, H. et al. (2006) Gene transfer of hepatocyte growth factor gene improves learning and memory in the chronic stage of cerebral infarction. Hypertension 47, 742-751.

120) Ishigaki, A., Aoki, M., Nagai, M., Warita, H., Kato, S., Kato, M. et al. (2007) Intrathecal delivery of hepatocyte growth factor from amyotrophic lateral sclerosis onset suppresses disease progression in rat amyotrophic lateral sclerosis model. J. Neuropathol. Exp. Neurol. 66, 1037-1044.

121) Koike, H., Ishida, A., Shimamura, M., Mizuno, S. Nakamura, T., Ogihara, T. et al. (2006) Prevention of onset of Parkinson's disease by in vivo gene transfer of human hepatocyte growth factor in rodent model: a model of gene therapy for Parkinson's disease. Gene Ther. 13, 1639-1644.

122) Takeuchi, D., Sato, N., Shimamura, M., Kurinami, H., Takeda, S., Shinohara, M. et al. (2008) Alleviation of $\mathrm{A} \beta$-induced cognitive impairment by ultrasound-mediated gene transfer of HGF in a mouse model. Gene Ther. 15, 561-571.

123) Kitamura, K., Iwanami, A., Nakamura, M., Yamane, J., Watanabe, K., Suzuki, Y. et al. (2007) Hepatocyte growth factor promotes endogenous repair and functional recovery after spinal cord injury. J. Neurosci. Res. 85, 2332-2342.

124) Kokuzawa, J., Yoshimura, S., Kitajima, H., Shinoda, J., Kaku, Y., Iwama, T. et al. (2003) Hepatocyte growth factor promotes proliferation and neuronal differentiation of neural stem cells from mouse embryos. Mol. Cell. Neurosci. 24, 190-197.

125) Oshima, K., Shimamura, M., Mizuno, S., Tamai, K., Doi, K., Morishita, R. et al. (2004) Intrathecal injection of HVJ-E containing HGF gene to cerebrospinal fluid can prevent and ameliorate hearing impairment in rats. FASEB J. 18, 212214.

126) Kato, N., Nemoto, K., Nakanishi, K., Morishita, R., Kaneda, Y., Uenoyama, M. et al. (2005) Nonviral gene transfer of human hepatocyte growth factor improves streptozotocin-induced diabetic neuropathy in rats. Diabetes 54, 846-854.

127) Morishita, R., Aoki, M., Hashiya, N., Makino, H., Yamasaki, K., Azuma, J. et al. (2004) Safety evaluation of clinical gene therapy using hepatocyte growth factor to treat peripheral arterial disease. Hypertension 44, 203-209.

128) Powell, R.J., Simons, M., Mendelsohn, F.O., Daniel, G., Henry, T.D., Koga, M. et al. (2008) Results of a double-blind, placebo-controlled study to assess the safety of intramuscular injection of hepatocyte growth factor plasmid to improve limb perfusion in patients with critical limb ischemia. Circulation 118, 58-65.

129) Yuan, B., Zhao, Z., Zhang, Y.R., Wu, C.T., Jin, W.G., Zhao, S. et al. (2008) Short-term safety and curative effect of recombinant adenovirus carrying hepatocyte growth factor gene on ischemic cardiac disease. In Vivo 22, 629-632.

130) Cui, Y.L., Meng, M.B., Tang, H., Zheng, M.H., Wang, Y.B., Han, H.X. et al. (2008) Recombinant human hepatocyte growth factor for liver failure. Contemp. Clin. Trials 29, 696-704.

131) Nayeri, F., Stromberg, T., Larsson, M., Brudin, L., Soderstrom, C. and Forsberg, P. (2002) Hepatocyte growth factor may accelerate healing in chronic leg ulcers: a pilot study. J. Dermatolog. Treat. 13, 81-86.

132) Date, K., Matsumoto, K., Shimura, H., Tanaka, M. and Nakamura, T. (1997) HGF/NK4 is a specific antagonist for pleiotrophic actions of hepatocyte growth factor. FEBS Lett. 420, 1-6.

133) Matsumoto, K. and Nakamura, T. (2006) Hepatocyte growth factor and the Met system as a mediator of tumor-stromal interactions. Int. J. Cancer 119, 477-483.

134) Matsumoto, K. and Nakamura, T. (2008) NK4 gene therapy targeting HGF-Met and angiogenesis. Front. Biosci. 13, 1943-1951.

135) Yano, S., Wang, W., Li, Q., Matsumoto, K., Sakurama, H., Nakamura, T. et al. (2008) Hepatocyte growth factor induces gefitinib resistance of lung adenocarcinoma with epidermal growth factor receptor-activating mutations. Cancer Res. 68, 9479-9487.

(Received Jan. 29, 2010; accepted Apr. 20, 2010) 


\section{Profile}

Toshikazu Nakamura was born in 1945. He graduated from the Osaka University Graduate School of Science in 1972 under instruction by Professor Takekazu Horio (Institute for Protein Research). Immediately following graduation, he was appointed to Assistant Professor, Department of Dental Anatomy (Professor Masayoshi Kumegawa), Josai Dental University in Saitama (1972-1975). Thereafter, he engaged in research (biochemistry and cell biology) for 2 years at the University of California-San Diego, with Professor Gordon H. Sato. Following 1977, he worked at the Institute for Enzyme Research, University of Tokushima (Professor Akira Ichihara), as an Instructor and Associate Professor. In Professor Ichihara's laboratory, he investigated hepatic metabolism using a primary culture system of rat hepatocytes. While conducting this

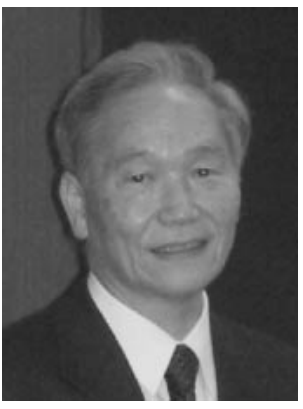
hepatic research, he discovered HGF as a hepatotrophic factor that triggers liver regeneration. Subsequently, he received the Promotion Award from the Japanese Biochemical Society and that from the Japanese Cancer Association, both in 1984. In 1988, he was invited to join the Faculty of Science, Kyushu University in Fukuoka, as a Professor, and soon succeeded in cloning the cDNA of human and rat HGF. In 1993, he transferred to Osaka University Graduate School of Medicine as a Professor of Biochemistry where he has demonstrated the roles of HGF in organogenesis, tissue regeneration and tumor malignancy. He demonstrated the therapeutic value of HGF for treating incurable diseases and the value of NK4 as an anti-tumor agent. He received the Princess Takamatsu Cancer Research Fund Prize in 1992, the Research Prize from the Yasuda Medical Foundation in 1994, the Mochida Memorial Foundation Prize in 1994, the Osaka Science Prize in 1994, the Inoue Prize for Science in 1995, the Nature Medicine-AnGes MG Biomedical Award in 2006, and the Medal with Purple Ribbon, also in 2006. He retired and was nominated as Professor Emeritus in 2008. Now, he continues his life's work as a Specially Appointed Professor at the Center for Advanced Science and Innovation, Osaka University.

\section{Profile}

Shinya Mizuno was born in 1962. He graduated from the Hokkaido University Graduate School of Veterinary Medicine, Department of Veterinary Surgery, in 1987, where he worked as Assistant Professor in the Department (1988-1993). In 1993, he transferred to the Institute of Experimental Animal Sciences, Osaka University Medical School and began studies on the pathogenetics of chronic kidney disease (CKD). In 1996, he received the Promotion Award from the Japanese Society of Veterinary Medicine for a study on the therapeutic effects of HGF on CKD. Since 1997, he has worked as a Research Associate, Assistant Professor and Instructor in Professor Nakamura's laboratory. Meanwhile, he demonstrated the physiological role of the HGF-c-Met system in various diseases. In 2004, he received the Award from the Japanese Society of

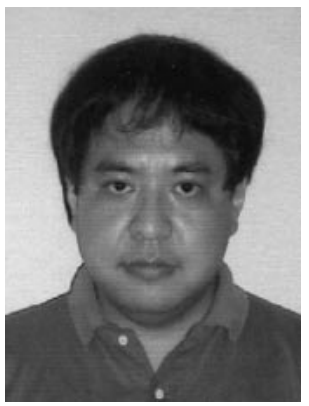
Regenerative Medicine. His major research subjects are molecular pathology and cell biology as they relate to therapeutic mechanisms. 